Centro Universitário de Brasília - UniCEUB

Faculdade de Ciências Jurídicas E Sociais - FAJS

LARISSA FONTENELLE DE MENDONÇA BARBOSA

FINANCIAMENTO ELEITORAL E DEMOCRACIA REPRESENTATIVA:

ESTUDO COMPARADO DOS MODELOS DE FINANCIAMENTO BRASILEIRO E FRANCÊS

BRASÍLIA 


\section{LARISSA FONTENELLE DE MENDONÇA BARBOSA}

FINANCIAMENTO ELEITORAL E DEMOCRACIA REPRESENTATIVA:

ESTUDO COMPARADO DOS MODELOS DE FINANCIAMENTO BRASILEIRO E FRANCÊS

Relatório final de pesquisa de Iniciação Científica apresentado à Assessoria de Pós-Graduação e Pesquisa pela Faculdade de Ciências Jurídicas e Sociais -FAJS

Orientação: Carlos Bastide Horbach

Brasília 


\title{
FINANCIAMENTO ELEITORAL E DEMOCRACIA REPRESENTATIVA: ESTUDO COMPARADO DOS MODELOS DE FINANCIAMENTO BRASILEIRO E FRANCÊS
}

\author{
Larissa Fontenelle de Mendonça Barbosa - UniCEUB, PIC voluntário Direito \\ larissafontenelle@hotmail.com
}

\author{
Carlos Bastide Horbach - UniCEUB, professor orientador \\ carloshorbach@uol.com.br
}

O modelo de financiamento eleitoral no Brasil sofreu significativa alteração no ano de 2015, quando, por meio do julgamento da Ação Direta de Inconstitucionalidade $\mathrm{n}$. 4.650 (ADI n. 4.650) e com a Lei n. 13.165, de 29 de setembro de 2015, chamada "Minirreforma eleitoral", pessoas jurídicas foram proibidas de doar recursos às campanhas eleitorais. $O$ trabalho investiga os modelos de financiamento eleitoral brasileiro e francês, e como estes influem na noção de 'democracia representativa' de seus respectivos países. Para isso, o trabalho vale-se do estudo comparado como método, contrastando as leis pátrias e francesas que cuidam do financiamento eleitoral, com o objetivo de analisar a experiência francesa e sugerir alternativas para o aperfeiçoamento do atual modelo de financiamento eleitoral no Brasil. Assim, o trabalho conclui que o modelo de financiamento eleitoral recentemente proposto no Brasil assemelha-se ao modelo francês, que adota modelo de financiamento eleitoral misto, predominantemente público, desde 1995. A pesquisa expõe aspectos em comum entre os referidos modelos, como o uso predominante de recursos públicos, proibição de doações a campanhas eleitorais por pessoas jurídicas que não sejam partidos políticos; e estipulação de limite máximo de gastos das campanhas eleitorais. O estudo comparado se mostra relevante no atual contexto jurídico-político brasileiro, pois novas formas de financiamento eleitoral vêm sendo debatidas no Congresso Nacional, e entender a experiência de outras democracias pode ajudar a estabelecer um modelo de financiamento eleitoral viável, sustentável, e, ainda, salutar para a 'democracia representativa' no Brasil.

Palavras-Chave: Financiamento Eleitoral. Democracia Representativa. ADI n. 4.650 
SUMÁRIO

1 INTRODUÇÃO

2 OBJETIVOS

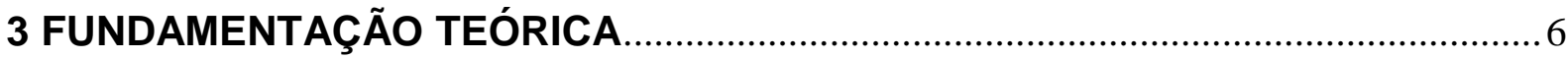

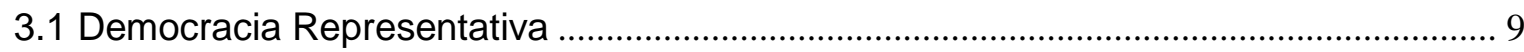

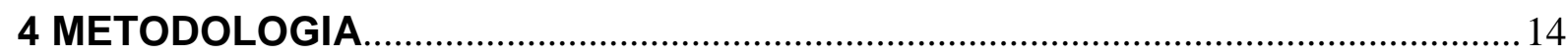

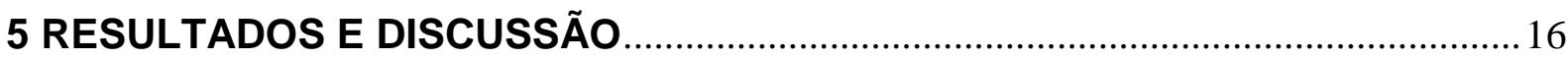

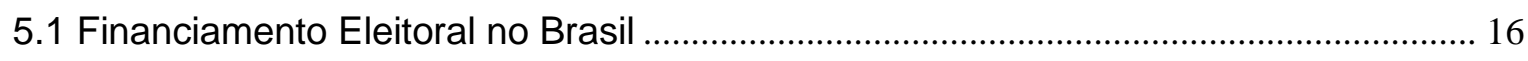

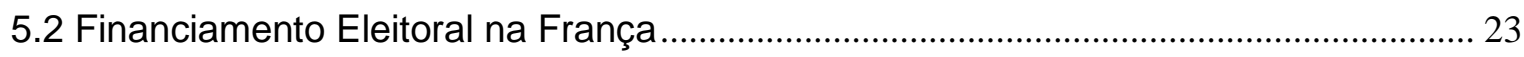

5.3 Análise dos pressupostos adotados na ADI n. 4.650/2015 ........................................... 32

5.4 Possibilidades para o aprimoramento da Democracia Representativa no Brasil ....... 38

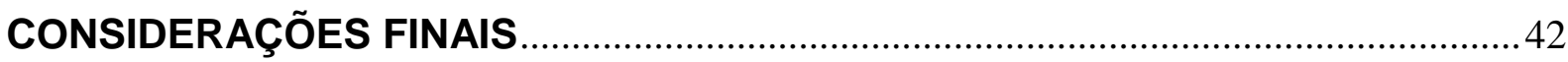

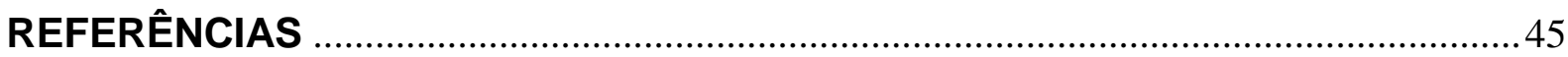




\section{INTRODUÇÃO}

O financiamento eleitoral é assunto relevante no cenário jurídico-político atual, estando relacionado diretamente aos ramos do Direito Eleitoral e Constitucional. Mais especificamente, a participação de pessoas jurídicas no financiamento eleitoral é tema controverso e não foi superado no Brasil, mesmo com a recente alteração da legislação para vedar as doações de pessoas jurídicas às campanhas eleitorais. Portanto, o presente trabalho realiza um estudo comparado com os modelos de financiamento eleitoral brasileiro e francês para investigar as (in)compatibilidades da participação de pessoas jurídicas no financiamento de campanhas.

Diante das recentes restrições impostas à participação de pessoas jurídicas no financiamento eleitoral com o julgamento do Supremo Tribunal Federal na ADI $n$. 4.650 e as consequentes alterações da Lei n. $13.165 / 15$, o presente trabalho investiga o novo formato de financiamento eleitoral em vigor no Brasil. Os referidos acontecimentos provocaram uma "reviravolta" nas práticas eleitorais no país, visto que os recursos angariados pelos candidatos até o ano de 2015 eram substancialmente oriundos de doações de pessoas jurídicas. Com a vedação desse tipo de doação, fazse necessário observar atentamente quais serão os novos problemas enfrentados no processo eleitoral brasileiro.

O presente trabalho expõe que as regras atuais de financiamento eleitoral no Brasil se assemelham às francesas. Isso porque, na França, contribuições de pessoas jurídicas são vedadas e o financiamento eleitoral se dá de forma regulada e rígida. Nesse sentido, o estudo investiga os reflexos da participação de pessoas jurídicas para a consolidação de uma Democracia Representativa nos modelos de financiamento eleitoral brasileiro e francês. A pesquisa conclui que, ao entender serem as contribuições de pessoas jurídicas ao financiamento eleitoral incompatíveis com o interesse público, o Brasil deveria adotar outras medidas, como: garantir a igualdade nas doações de pessoas físicas, e incentivar as doações destas, entre outras, para viabilizar o atual modelo de financiamento predominantemente público e assegurar a representatividade na política. 


\section{OBJETIVOS}

O presente trabalho realiza uma comparação entre as legislações eleitorais brasileira e francesa, no que tange o financiamento de campanhas, com o objetivo de contribuir para a elaboração de novas alternativas para o processo eleitoral brasileiro; com o fim precípuo de fortalecer a democracia representativa no Brasil.

O estudo é balizado pelos argumentos, aqui apresentados como "pressupostos", adotados no julgamento da ADI n. 4.650', que fizeram o Suprema Tribunal Federal declarar a inconstitucionalidade das doações de pessoas jurídicas às campanhas no Brasil e instar o Congresso Nacional a realizar alterações no processo eleitoral.

Os "pressupostos" adotados no julgamento da referida ADI são:

(i) Incompatibilidade do exercício de direitos políticos com a natureza das pessoas jurídicas; ${ }^{2}$

(ii) $\mathrm{O}$ direito de expressão de pessoas jurídicas não seria violado com a proibição de suas doações, porque, antes de expressar preferências políticas, as doações denotariam uma estratégia de empresas para estreitar relações com o poder público; ${ }^{3}$

(iii) Haveria ofensa ao princípio da igualdade se autorizada doação por parte de outras pessoas jurídicas, mas vedadas as doações por entidades sem fim lucrativos e sindicatos, como anteriormente posto pela lei. ${ }^{4}$

(iv) A vedação de doações por pessoas jurídicas não dificultaria o custeio das campanhas eleitorais, uma vez que os partidos continuariam tendo acesso aos recursos do fundo partidário e à

\footnotetext{
${ }^{1}$ BRASIL. Supremo Tribunal Federal. Acórdão na ADI n. 4.650. ADI n. 4.650. Tribunal Pleno. Requerente: Conselho Federal da Ordem dos Advogados do Brasil - CFOAB. Intimados: Presidente da República e Congresso Nacional. Relator: Luiz Fux. Brasília, 17 de setembro de 2015. Disponível em: <http://www.stf.jus.br/portal/processo/verProcessoAndamento.asp?incidente=4136819 >. Acesso em: $24 \mathrm{abr}$. 2016.

${ }^{2}$ Ibidem.

${ }^{3}$ Ibidem.

${ }^{4}$ Ibidem.
} 
propaganda eleitoral gratuita, além de poderem contar com doações de pessoas físicas; ${ }^{5}$

(v) Não mereceria prosperar a alegação de que a vedação de doações não impediria as pessoas jurídicas de influenciar o processo político, pois estas se valeriam de formas ilícitas; ressaltando que se faz necessária, como sempre, a preocupação com o fortalecimento de mecanismos de fiscalização; 6

Assim, analisa-se como esses pressupostos são tratados no modelo de financiamento eleitoral francês, que também veda doações de pessoas jurídicas de direito privado. Ao fim, o trabalho aponta falhas e virtudes do modelo de financiamento eleitoral francês com as quais é possível traçar um paralelo com o atual contexto eleitoral brasileiro, no sentido de aprimorar a democracia representativa no Brasil.

\footnotetext{
${ }^{5}$ BRASIL. Supremo Tribunal Federal. Acórdão na ADI n. 4.650. ADI n. 4.650. Tribunal Pleno. Requerente: Conselho Federal da Ordem dos Advogados do Brasil - CFOAB. Intimados: Presidente da República e Congresso Nacional. Relator: Luiz Fux. Brasília, 17 de setembro de 2015. Disponível em: <http://www.stf.jus.br/portal/processo/verProcessoAndamento.asp?incidente=4136819 >. Acesso em: 24 abr.

${ }^{6}$ Ibidem.
} 


\section{FUNDAMENTAÇÃO TEÓRICA}

Como premissa do presente estudo, nota-se a influência que o dinheiro tem no resultado eleitoral. ${ }^{7}$ Conforme pesquisa realizada em 2012, referente às eleições de 2010, que analisa a relação entre volume de gastos e possibilidade de sucesso dos candidatos, nas eleições de deputado federal, dos 513 eleitos, 369 estavam entre os que mais gastaram no seu estado; e os eleitos gastaram na média nacional o dobro dos não eleitos mais próximos da eleição. ${ }^{8}$

No Brasil, o limite de gastos das campanhas deveria ser fixado por lei (como na França), mas, na prática, esse limite não era estabelecido ${ }^{9}$. Assim, ficava a cargo dos partidos políticos a fixação de valores máximos gastos nas campanhas; até a Lei n. 13.165/15 entrar em vigor, oferecendo ao Tribunal Superior Eleitoral a função de estabelecer o limite de gastos. ${ }^{10}$ Os gastos geralmente envolvem espaço publicitário nas mídias, elaboração de panfletos e demais materiais de campanha, contratação de cabos eleitorais, de prestadores de serviço, de "marqueteiros", dentre outras despesas. ${ }^{11}$ Nessa lógica, diversos outros estudos sinalizam a forte relação entre os gastos eleitorais e os resultados das eleições no Brasil. ${ }^{12}$

Na França, diferentemente do Brasil até o ano de 2015, a influência do dinheiro no resultado eleitoral é equalizada devido ao limite de gastos de campanhas

\footnotetext{
${ }^{7}$ ARAÚJO, Victor; SILOTTO, Graziele; CUNHA, Lucas Rodrigues. Capital político e financiamento eleitoral no Brasil: uma análise empírica das estratégias das empresas na alocação de recursos de campanha. Teoria $e$ Sociedade, n. 23.2, p. 126-158, jul./dez. 2015; SACCHET, Teresa; SPECK, Bruno Wilhelm. Financiamento Eleitoral e Representação Política: O peso do dinheiro e o desequilíbrio de gênero nas esferas legislativas. $34^{\circ}$ encontro anual da ANPOCS, Caxambu -MG, out. 2010, p. 8.

${ }^{8}$ BACKES, Ana Luiza; SANTOS, Luiz Cláudio Pires dos. Gastos em campanhas eleitorais no Brasil. Cadernos ASLEGIS, Brasília, n. 46, maio/ago. 2012, p. 58

9 XAVIER, Allan Ferreira; SILVA, Matheus Passos. (Coord.). O financiamento da campanha eleitoral e sua influência na representação política. Brasília: Vestnik, 2014, p. 32

10 BRASIL. Lei n. 13.165, de 29 de setembro de 2015. Disponível em: <http://www.planalto.gov.br/ccivil_03/_ato2015-2018/2015/lei/113165.htm >. Acesso em: 24 abr. 2016.

11 SARMENTO, Daniel; OSÓRIO, Aline. Eleições, dinheiro e democracia: a ADI 4650 e o modelo de financiamento de campanhas eleitorais. Direitos Fundamentais e Justiça, ano 8, n. 26, jan./mar. 2014, p. 18

12 BRASIL. Câmara dos Deputados. Proposta estabelece limites para gastos eleitorais. Disponível em: <http://www2.camara.leg.br/camaranoticias/noticias/POLITICA/475470-PROPOSTA-ESTABELECE-

LIMITES-PARA-GASTOS-ELEITORAIS.html>. Acesso em: 18 mar. 2017; SARMENTO, Daniel; OSÓRIO, Aline. Eleições, dinheiro e democracia: a ADI 4650 e o modelo de financiamento de campanhas eleitorais. Direitos Fundamentais e Justiça, ano 8, n. 26, jan./mar. 2014, p. 17; FILHO, Dalson Britto Figueiredo. Gastos Eleitorais: os determinantes das eleições? Estimando a influência dos gastos de campanha nas eleições de 2002. Revista Urutágua, v. 8, p. 1-10, 2005; SAMUELS, David. Financiamento de Campanhas no Brasil e Propostas de Reforma. Suffragium, v. 3, n. 4, p. 11-28, jan./jun. 2007; SPECK, Bruno; WAGNER, Mancuso. O que faz a diferença? Gastos de campanha, capital, política, sexo e contexto municipal nas eleições para prefeito em 2012. Cadernos Adenauer XIV, n. 2, 2013.
} 
eleitorais estabelecido por lei. Nas eleições presidenciais, por exemplo, os dois candidatos do segundo turno das eleições gastam quase os mesmos valores, respeitando o teto de $€ 22.000 .000,00$ (vinte e dois milhões de euros). ${ }^{13}$

Mister entender que o dinheiro não é fator determinante do sucesso nos resultados eleitorais, pois não é uma variável independente, e tende a fluir para candidatos mais fortes, com mais chances. Mas, o que resta claro é que a competitividade depende diretamente do valor investido, e que, sem gastar muito, as chances de eleição são reduzidas, no Brasil. Por consequência, nota-se os reflexos da relação "dinheiro" e "sucesso eleitoral" sobre a representatividade. Por exemplo, se a eleição é mais cara, o candidato ou partido que tem menos dinheiro enfrentará maiores dificuldades e será menos competitivo para eleger-se. ${ }^{14}$

Evidenciada a importante relação entre o sucesso e os gastos em campanhas eleitorais; se os gastos são tão importantes para o pleito eleitoral, por que vedar a participação de pessoas jurídicas no financiamento eleitoral? Há quem defenda que pessoas jurídicas deveriam participar do financiamento eleitoral, visto que são capazes de proporcionar valores significativos às campanhas eleitorais. Nesse sentido, o fato de candidatos disporem de muitos recursos e de realizarem altos gastos com suas campanhas não deveria ser entendido, necessariamente, como algo negativo. Pelo contrário, a elevação dos custos eleitorais poderia sinalizar eleições competitivas, ou seja, uma virtude democrática. ${ }^{15}$

Além disso, argumenta-se que pessoas jurídicas também têm interesses; portanto, querem ver eleitos sujeitos que se engajarão em determinadas políticas que as beneficiem - como os cidadãos também querem. Assim, as contribuições de pessoas jurídicas no financiamento eleitoral seriam uma forma de ter acesso aos candidatos quando eleitos, mas não significando um condicionamento das decisões destes em favor das pessoas jurídicas. ${ }^{16}$

\footnotetext{
${ }^{13}$ FRANÇA. Décret $n^{\circ}$ 2009-1730 du 30 décembre 2009 portant majoration du plafond des dépenses électorales. Disponível em:

<https://www.legifrance.gouv.fr/affichTexte.do?cidTexte=JORFTEXT000021571255\&categorieLien=cid>. Acesso em: 17 mar. 2017

${ }^{14}$ BACKES, Ana Luiza; SANTOS, Luiz Cláudio Pires dos. Gastos em campanhas eleitorais no Brasil. Cadernos ASLEGIS, Brasília, n. 46, maio/ago. 2012, p. 58

${ }^{15}$ CASAS-ZAMORA, Kevin; ZOVATTO, Daniel. op.cit., p. 23

${ }^{16}$ Ibidem, p. 20.
} 
Por outro ângulo, diversos estudos indicam que pessoas jurídicas, especialmente se considerarmos as empresas, tornam-se doadoras na medida em que têm expectativa de retorno e garantias das capacidades dos representantes para influenciar nos processos de decisão (acessar recursos, propor ou barrar agendas e, por conseguinte, auxiliar no direcionamento de benefícios a grupos específicos). ${ }^{17}$ Assim, alega-se que as intenções das pessoas jurídicas no financiamento eleitoral prejudicariam 0 interesse público, privatizando decisões políticas. ${ }^{18}$ Ademais, defende-se que, por não serem cidadãos, logo, não terem direitos políticos, ${ }^{19}$ pessoas jurídicas não teriam direito de influenciar o pleito eleitoral.

Dentre outras razões argumentadas para vedar a participação de pessoas jurídicas no financiamento eleitoral, uma razão importante seria que o poder econômico destas, frente às demais fontes de contribuição, desequilibraria a corrida eleitoral. ${ }^{20}$ Portanto, tal preponderância do poder econômico traria prejuízos à legitimidade do processo eleitoral. ${ }^{21}$

Pelo exposto, países que se pretendem democracias representativas devem atentar-se ao financiamento eleitoral, visto que representantes são eleitos por meio de processo eleitoral no qual os recursos que dispõem têm impacto em um eventual sucesso eleitoral. ${ }^{22}$ Por consequência, a participação de pessoas jurídicas, apenas por serem capazes de disponibilizar largos recursos aos candidatos, também traz reflexo no resultado eleitoral. O que resta ser investigado, no entanto, é se o reflexo dessa participação é compatível e funcional para a democracia representativa.

\footnotetext{
${ }^{17}$ ARAÚJO, Victor; SILOTTO, Graziele; CUNHA, Lucas Rodrigues. Capital político e financiamento eleitoral no Brasil: uma análise empírica das estratégias das empresas na alocação de recursos de campanha. Teoria e Sociedade, n. 23.2, p. 151, 2015

${ }^{18}$ CASAS-ZAMORA, Kevin; ZOVATTO, Daniel. The Cost of Democracy: essays on Political Finance in Latin America. Costa Rica: IDEA, 2016, p. 20

${ }^{19}$ BRASIL. Constituição (1988). Constituição da República Federativa do Brasil. Brasília: Senado Federal, 2010.

${ }^{20}$ SALGADO, Eneida Desireé. Abuso do poder econômico e financiamento das campanhas eleitorais. Curitiba. Disponível em: $<$ http://www.paranaeleitoral.gov.br/artigo_impresso.php?cod_texto=10>. Acesso em.: 27 out 2007

${ }^{21}$ CASAS-ZAMORA, op. cit., p. 21

${ }^{22}$ SACCHET, Teresa; SPECK, Bruno Wilhelm. Financiamento Eleitoral e Representação Política: O peso do dinheiro e o desequilíbrio de gênero nas esferas legislativas. $34^{\circ}$ encontro anual da ANPOCS, Caxambu -MG, out. 2010, p. 8
} 


\subsection{Democracia Representativa}

Como explica Keane, em "A vida e morte da Democracia", desde sua origem, a democracia vinha sendo praticada como forma de autogoverno de iguais, que se dava por meio de assembleias, até sofrer uma "grande mutação" e passar a trazer a noção de representação. ${ }^{23}$ A "representação política" solidificou-se com longos anos de fortalecimento do poder parlamentar, especialmente na Inglaterra, nos Estados Unidos e na França. Mas, ao contrário do que se imagina, a difusão de parlamentos pela Europa não traçou rota direta até a democracia representativa. Isso porque os parlamentos eram submetidos à dominação de monarcas autocentrados. ${ }^{24}$ Assim, o advento dos parlamentos europeus não correspondeu à concretização da representação do "povo".

Em verdade, os parlamentos teriam sofrido com pressões externas por muito tempo para adequarem-se, até serem forçados a internalizar o direito universal do "povo" 25 e o desenvolvimento de instituições representativas teria ocorrido por necessidade política. ${ }^{26}$

O termo "Democracia Representativa" só foi cunhado no fim do século XVIII, por pensadores políticos e redatores de constituições - séculos depois da internalização da noção de representação na democracia; e consistia em um novo tipo de governo, fundamentado no consentimento popular. ${ }^{27}$ Alexander Hamilton é considerado o primeiro norte-americano a relacionar as palavras "democracia" e "representação". O Federalista afirmava que governos populares poderiam ser regulares e duráveis se assumissem a forma de "democracia representativa". Ou seja, desde que o direito de eleição fosse bem assegurado e regulamentado, e o exercício de autoridades executivas, judiciárias e legislativas fosse investido em pessoas selecionadas, escolhidas realmente e não nominalmente pelo povo. ${ }^{28}$

Desde então, muita tinta e muito sangue foram derramados para tentar definir o que seria "representação", quem poderia representar e o que aconteceria

\footnotetext{
${ }^{23}$ KEANE, John. A vida e a morte da democracia. São Paulo: Edições 70, 2010, p. 171.

${ }^{24}$ Ibidem, p. 190.

${ }^{25}$ Ibidem, p. 194.

${ }^{26}$ STEPHENSON, Carl. Medieval Institutions. Ithaca, Nova York: Cornell University Press, 1954. p. 138

${ }^{27}$ KEANE, John. op.cit., p. 171.

${ }^{28}$ Ibidem, p. 172.
} 
com o representante que não seguisse a vontade expressada pelo eleitorado. ${ }^{29} \mathrm{~A}$ mudança da democracia de assembleia até a Democracia Representativa foi acontecendo de forma pouco coerente, resultando em diversas formas concretas de Democracias Representativas. O que permanecia comum a todas era a invenção de instituições representativas. ${ }^{30}$

Desta feita, Democracia Representativa foi, nas palavras de Keane, "algo novo sob o sol", pois trouxe inovações como: constituições escritas, judiciários independentes, leis procedimentais, eleições periódicas de candidatos a legislaturas, prazo limitado de permanência em cargos políticos, partidos políticos e liberdade de imprensa. ${ }^{31}$ Aos poucos, as Democracias Representativas foram expandindo, a ponto de, recentemente, contemplarem toda a população; a exemplo do direito de voto que foi garantido a certos grupos antes excluídos, como escravos, mulheres e trabalhadores. ${ }^{32}$

Democracia pode ser conceituada, de forma demasiadamente simplista como "governo do povo, pelo povo, para o povo", conforme critério quantitativo. ${ }^{33}$ Conceitualmente, democracia contrastaria com outros regimes políticos, como autoritarismo e o totalitarismo. Atualmente, existem inúmeras definições de democracia, tendo em vista que mesmo países que poderiam ser considerados oligárquicos ou despóticos por alguns, classificam-se como democráticos. ${ }^{34}$

A Democracia "Representativa", também chamada de "indireta", distinguese pela escolha dos representantes que exercerão o poder. ${ }^{35}$ Hoje, quase todas as democracias são representativas; com exceções clássicas, como a democracia semidireta suíça. Esse fato se explica pela impossibilidade de reunir milhões de cidadãos para resolver problemas comuns; além da incapacidade de o povo compreender problemas técnicos de toda natureza. ${ }^{36}$

\footnotetext{
${ }^{29}$ KEANE, John. A vida e a morte da democracia. São Paulo: Edições 70, 2010, p. 172.

${ }^{30}$ Ibidem, p. 174.

${ }^{31}$ Ibidem, p. 174.

${ }^{32}$ Ibidem, p. 176.

${ }^{33}$ CUNHA, André Luiz Nogueira da. Direitos políticos: representatividade, capacidade eleitoral e inelegibilidades. São Paulo: Juarez de Oliveira, 2004, p. 18

34 SARMENTO, Daniel; OSÓRIO, Aline. Eleições, dinheiro e democracia: a ADI 4650 e o modelo de financiamento de campanhas eleitorais. Direitos Fundamentais e Justiça, ano 8, n. 26, p. 18, jan./mar. 2014

${ }^{35}$ DALLARI, Dalmo de Abreu. Elementos de teoria geral do estado. 22. ed. São Paulo: Saraiva, 2001, p. 152159.

${ }^{36}$ FERREIRA FILHO, 1999, apud CUNHA, André Luiz Nogueira da. Direitos políticos: representatividade, capacidade eleitoral e inelegibilidades. São Paulo: Juarez de Oliveira, 2004, p. 19
} 
Em uma democracia não poderia haver espaço para concepções ou soluções com base no obscurantismo, na injustiça, ou em qualquer abuso do poder de autoridade ou econômico, porque essas características seriam desvalores no convívio social. ${ }^{37}$ Ademais, é preciso que o indivíduo socialize, perceba outros pontos de vista e busque nas alternativas de representantes políticos aquele que mais se adeque às suas percepções. Dessa forma, Democracia Representativa se mostra, para muitos, a versão mais civilizada de democracia estabelecida até o momento. ${ }^{38}$

É possível notar que a Democracia Representativa vem sendo exaltada por longos anos; mas, mesmo tendo se consolidado como melhor alternativa de forma de governar, nas últimas décadas vem perdendo seu "encanto" no Ocidente. Até mesmo democracias antigas e sólidas vêm sofrendo com desconfiança dos representados para com seus representantes, insatisfação com governos e baixa identificação entre eleitorado e partidos políticos. ${ }^{39}$

No mesmo sentido, Meire Marques e Thiago Ribeiro expõem bem o que convencionou-se chamar de "crise de representatividade" - muito argumentada no julgamento da ADI n. 4.650:

A insatisfação com o sistema político a demonstrar a crise da
representatividade é refletida pela ausência de respostas aos anseios da
sociedade civil, com o distanciamento do representante no período pós-
eleitoral daqueles que foram responsáveis por lhe atribuir aquilo que é, antes
de tudo, um exercício de responsabilidade, qual seja, representar
legitimamente os interesses dos eleitores. Tal crise também pode ser
vislumbrada no abstencionismo dos eleitores - o qual demonstra a
incredulidade no sistema- e na patologia da representação, a significar que
os cidadãos se consideram cada vez menos representados. ${ }^{40}$

Além da explanada "crise de representatividade", há diversas reflexões feitas, especialmente na Ciência Política, apresentando as controvérsias (e até a "impossibilidade", para alguns) ${ }^{41}$ de "democracia" e "representação" andarem juntas.

\footnotetext{
${ }^{37}$ FERREIRA FILHO, 1999, apud CUNHA, André Luiz Nogueira da. Direitos políticos: representatividade, capacidade eleitoral e inelegibilidades. São Paulo: Juarez de Oliveira, 2004, p. 14.

${ }^{38}$ ANKERSMIT, Frank. Democracia Representativa. Revista Antíteses, Londrina, v. 6, n.12, jul./dez. 2013, p. 466.

${ }^{39}$ Ibidem, p. 457.

${ }^{40}$ MARQUES, Meire Aparecida; RIBEIRO, Thiago Bao. Para além da democracia representativa: uma crítica ao modelo tradicional de representatividade política nas democracias modernas. Revista Jurídica UniCuritiba, Curitiba, v. 2, n. 39, p. 346. Grifo nosso.

${ }^{41}$ PITKIN, Hanna Fenichel. Representation and Democracy: Uneasy Alliance. Scandinavian Political Studies. Denmark; Finland; Iceland; Norway; Sweden: v. 27, n. 3, p.335, set/2004.
} 
No entanto, é preciso reconhecer que, no âmbito jurídico, a democracia representativa ainda se mostra como regime político mais difundido e defendido atualmente.

Cabe esclarecer que tanto o Brasil, quanto a França, são democracias representativas. Esses três países estabelecem que em seus poderes executivo e legislativo, seus cidadãos serão representados por figuras políticas eleitas periodicamente para cargos pré-estabelecidos. ${ }^{42} \mathrm{Na}$ democracia brasileira, por exemplo, a representação está consagrada na Constituição Federal da República do Brasil, em seu parágrafo único, do art. $1^{\circ}$, que dita "todo poder emana do povo, que o exerce por meio de seus representantes eleitos ou diretamente, nos termos desta Constituição". 43

Desse modo, as duas democracias representativas estudadas dependem de processos eleitorais que legitimem os representantes. Isso porque Democracias Representativas encontram no sistema eleitoral uma forma significativa de manifestação de sua legitimidade; o que acontece pela lisura na composição do corpo eleitoral, no sufrágio esclarecido, consciente e livre de qualquer forma de coação ou pressão, e pela apuração dos votos sem ilegalidade nem fraude. É dessa forma que a representação do povo ganha importância. ${ }^{44}$

Canotilho assim leciona sobre a relevância do processo eleitoral para a democracia:

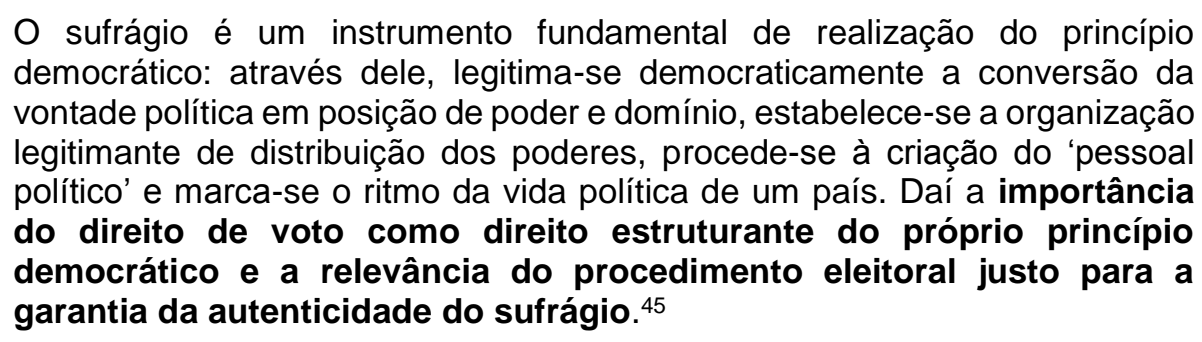

No Direito Eleitoral, a meta fundamental do processo eleitoral é a correta aplicação da lei específica na eleição dos representantes do povo, de forma a proteger de vícios, fraudes e violência, o processo pelo qual a vontade de cada cidadão se manifesta. ${ }^{46}$

\footnotetext{
${ }^{42}$ MILL, John Stuart. Representative government. Kitchener: Batoche Books, 2001, p. 57

${ }^{43}$ BRASIL. Constituição (1988). Constituição da República Federativa do Brasil. Brasília: Senado Federal, 2010.

${ }^{44}$ SILVEIRA, José Neri da. Aspectos do processo eleitoral. Porto Alegre: Livraria do advogado, 1998, p. 15

${ }^{45}$ CANOTILHO, José Joaquim Gomes. Direito constitucional e teoria da constituição. 3.ed. Coimbra: Almedina, 1998. p. 93-96. Grifo nosso.

${ }^{46}$ SILVEIRA, op. cit., p. 16
} 
Thomas Paine, político inglês, afirmava que a Democracia Representativa nivelava a competição de poder, por ser um sistema capaz de abarcar vários interesses e alcançar todo um território e população. Além disso, colocava que a Democracia Representativa estimulava 0 arejamento de interesses e opiniões diferentes, dando espaço para novas lideranças guiadas pelo mérito. ${ }^{47}$

Todavia, o entendimento de Paine pode ser questionado. Atualmente pairam dúvidas sobre se há mesmo tal circulação de interesses e se as lideranças são mesmo meritocráticas. O que levanta então a dúvida central do presente trabalho: hoje, o financiamento eleitoral não teria peso no arejamento de interesses e no estabelecimento de lideranças, o que não fora idealizado por Paine à época? Nesse sentido, o presente trabalho estuda como a participação de pessoas jurídicas no financiamento eleitoral afeta a representação democrática.

${ }^{47}$ KEANE, John. A vida e a morte da democracia. São Paulo: Edições 70, 2010. p. 173 


\section{METODOLOGIA}

A presente pesquisa segue a linha sócio-jurídica, partindo da noção de "Democracia Representativa" da Ciência Política, combinada com um estudo comparado da legislação brasileira com a legislação da França para apurar os reflexos da não participação de pessoas jurídicas no financiamento eleitoral para democracias representativas. Assim, adotou-se o método comparativo para investigar semelhanças e diferenças entre as legislações estudadas. ${ }^{48}$

Cumpre esclarecer que o estudo comparado não tem intenção de defender a possibilidade da mera importação de determinada legislação eleitoral já existente em outro país. De forma alguma se pretenderia a transposição de um sistema simplesmente por este ser considerado bem-sucedido em outro país, pois, como bem se sabe, é preciso ter em mente a realidade política e sociológica do lugar em análise - especialmente em estudos comparados.

Importante destacar que a pesquisa proposta apresenta dificuldades típicas de estudos comparados. Cada um dos países estudados tem seu próprio sistema político, com regimes, cargos eletivos e organização institucional. $O$ trabalho enfrenta essa dificuldade, sem desconsiderar eventuais diferenças.

Superou-se também outra dificuldade ao se optar por investigar o financiamento eleitoral apenas em nível federal. Muito embora fosse também importante considerar as eleições em outros níveis (estaduais, distritais, locais, etc.) para se investigar a representatividade política nos países estudados, entendeu-se inviável por estender demasiadamente o estudo. Dessa maneira, a pesquisa concentra-se apenas nas eleições presidenciais e parlamentares em nível federal.

Assim, na busca de sugestões para o financiamento de campanhas eleitorais no Brasil, o trabalho tem em consideração o contexto brasileiro, o momento histórico, a forma de engajamento político existente, a noção de civilidade dos eleitores, entre diversos outros aspectos da realidade político-social brasileira.

\footnotetext{
${ }^{48}$ MARCONI, Marina de Andrade; LAKATOS, Eva Maria. Fundamentos de Metodologia Científica. 7. ed. São Paulo: Atlas, 2010, p. 107
} 
Para realizar o estudo proposto, o trabalho se vale do método comparativo e adota como técnicas predominantes as pesquisas bibliográfica ${ }^{49}$ e documental (leis e decisões judiciais). ${ }^{50}$

${ }^{49}$ MARCONI, Marina de Andrade; LAKATOS, Eva Maria. Fundamentos de Metodologia Científica. 7. ed. São Paulo: Atlas, 2010, p. 183

${ }^{50}$ Ibidem, p. 174 


\section{RESULTADOS E DISCUSSÃO}

O presente trabalho realiza um estudo comparado das leis brasileiras e francesas que regulam a participação de pessoas jurídicas no financiamento eleitoral. Portanto, este capítulo é dividido em quatro blocos. No primeiro, é realizada análise da legislação eleitoral brasileira no que toca as doações de pessoas jurídicas desde a promulgação da Constituição de 1988. A análise se estende até o ano de 2015, com o julgamento da Ação Direta de Inconstitucionalidade n. 4.650 (ADI n. 4.650) pelo Supremo Tribunal Federal e termina com a promulgação da Lei n. 13.165, de 29 de setembro de 2015.

Em seguida, parte-se para a análise da legislação sobre o financiamento eleitoral francês e como o país veda contribuições de pessoas jurídicas em seus processos eleitorais. Também é feita uma revisão bibliográfica para averiguar como a não participação de pessoas jurídicas no financiamento eleitoral é vista pela opinião pública, e suas consequências na democracia francesa.

No terceiro bloco, é realizada a análise de como os pressupostos adotados no julgamento da ADI n. 4.650/2015 são entendidos na legislação francesa. E, por fim, no último bloco do capítulo, são discutidas algumas possibilidades para o aprimoramento da democracia representativa no Brasil.

\subsection{Financiamento Eleitoral no Brasil}

Desde a promulgação da Constituição Federal de 1988, o Brasil vem alterando a forma como autoriza contribuições para a realização de campanhas eleitorais. Com a instituição da ordem democrática em 1988, optou-se por manter a Lei n. 5.682, de 21 de julho de 1971, denominada Lei Orgânica dos Partidos Políticos, que vedava contribuições de pessoas jurídicas a partidos políticos e campanhas eleitorais. ${ }^{51}$

51 BRASIL. Lei n. 5.682, de 21 de julho de 1971. Lei orgânica dos partidos. Disponível em: <http://www.planalto.gov.br/ccivil_03/leis/1970-1979/L5682.htm>. Acesso em: 20 mar. 2017. 
Anos mais tarde, escândalos de corrupção relacionados à campanha eleitoral do ex-Presidente da República, Fernando Collor de Mello, deflagraram investigações e a formação de uma Comissão Parlamentar de Inquérito para apurar o envolvimento do então presidente como sócio oculto de Paulo César Farias, extesoureiro de sua campanha, em atividades de corrupção. Os escândalos e o cenário político culminaram no impeachment do Presidente Collor. ${ }^{52}$

Dessa forma, viu-se a necessidade de alterar a legislação que cuidava do financiamento eleitoral. O entendimento à época era de que a legislação vigente era "hipócrita" por insistir na proibição de contribuições de empresas quando tal proibição seria inviável. Assim, concluiu-se que melhor seria autorizar as doações de pessoas jurídicas para que a relação público e privado fosse bem fiscalizada e não se desse por meios tortuosos. ${ }^{53}$

A nova legislação foi elaborada para autorizar as referidas contribuições. Aprovou-se a Lei n. 8.713, de 30 de setembro de 1993, regulando as eleições do ano seguinte e passando a autorizar pessoas jurídicas a doarem aos pleitos eleitorais. ${ }^{54}$ Em seguida, foram aprovadas a Lei n. 9.096, de 19 de setembro de 1995, que dispõe sobre partidos políticos, ${ }^{55}$ e a Lei n. 9.504, de 30 de setembro de 1997, que estabelece normas para as eleições ${ }^{56}$ - ambas em vigor até hoje, com alterações.

A partir da nova legislação eleitoral, o financiamento eleitoral passou a funcionar com recursos privados e públicos, ou seja, de forma mista. O financiamento privado podia se dar por doações de (i) pessoa jurídica, que podia contribuir para campanhas eleitorais em até $2 \%$ (dois por cento) de seu faturamento anual bruto; ou de (ii) pessoa física, que podia doar até 10\% (dez por cento) de seu rendimento bruto

\footnotetext{
${ }^{52}$ SALLUM JR., Brasílio; CASAROES, Guilherme Stolle Paixão e. O impeachment do presidente Collor: a literatura e o processo. Lua Nova, n. 82, p. 163-200, 2011. Disponível em: $<$ http://www.scielo.br/scielo.php?script=sci_arttext\&pid=S0102-64452011000100008\&lng=en\&nrm=iso>. Acesso em: 03 out. 2016.

${ }^{53}$ BRASIL. Supremo Tribunal Federal. Acórdão na Ação Direta de Inconstitucionalidade. ADI n. 4.650. Tribunal Pleno. Requerente: Conselho Federal da Ordem dos Advogados do Brasil - CFOAB. Intimados: Presidente da República e Congresso Nacional. Relator: Luiz Fux. Voto do Ministro Gilmar Mendes. Brasília, 17 de setembro de 2015. Disponível em: <http://www.stf.jus.br/portal/processo/verProcessoAndamento.asp?incidente=4136819 $>$. Acesso em: 24 abr. 2016.

${ }^{54}$ Ibidem.

${ }^{55}$ BRASIL. Lei n. 9.096, de 19 de setembro de 1995. Dispõe sobre partidos políticos, regulamenta os arts. 17 e 14, $\S 3^{\circ}$, inciso V, da Constituição Federal. Disponível em: 〈http://www.planalto.gov.br/ccivil_03/leis/L9096.htm >. Acesso em: 24 abr. 2016.

${ }^{56}$ BRASIL. Lei $n$. 9.504, de 30 de setembro de 1997. Estabelece normas para as eleições. Disponível em: < http://www.planalto.gov.br/ccivil_03/LEIS/L9504.htm >. Acesso em: 24 abr. 2016.
} 
no ano anterior em dinheiro, ou doar bens estimáveis em dinheiro de até $R \$ 50.000,00$ (cinquenta mil reais). ${ }^{57}$ Vedava-se apenas as doações de: entidade ou governos estrangeiros, autoridade ou órgãos públicos, autarquias, empresas públicas, concessionárias de serviço público, sociedade de economia mista, fundações da administração pública indireta. Ainda, as campanhas eleitorais podiam contar com o financiamento público, por meio do Fundo Partidário e por acesso gratuito ao rádio e à televisão. ${ }^{58}$

Passadas quase duas décadas desde a elaboração das referidas leis, a política brasileira vê-se acometida por novos escândalos, dessa vez ainda mais gravosos, indicando que a imiscuição entre o poder público e o setor privado tinha relação direta com o financiamento de campanha eleitoral. O escândalo da "Operação Lava Jato" da Polícia Federal e seus diversos desdobramentos, sem esquecer do prévio escândalo do "Mensalão", ainda que de forma não explícita, provocaram o colapso do governo da Presidente Dilma Rousseff; que também veio a sofrer um impeachment. 59

Nota-se que o padrão se repete, pois, o debate sobre financiamento eleitoral ganha força em momento político semelhante ao caso Collor, narrado anteriormente. Porém, agora com o discurso contrário. Percebeu-se que as contribuições de pessoas jurídicas, autorizadas desde 1993, serviam como forma de legitimar pagamentos de empresas a figuras políticas; pagamentos estes referentes a benefícios ilicitamente concedidos por estas àquelas.

Com a propositura da Ação Direta de Inconstitucionalidade n. 4.650 (ADI n. 4.650) pelo Conselho Federal da Ordem dos Advogados, intensificou-se o debate sobre a possibilidade de tornar a proibir as doações de pessoas jurídicas. Desta feita, é perceptível que o debate acerca do financiamento eleitoral nunca fora exaurido e é

\footnotetext{
${ }^{57}$ BRASIL. Lei $n$. 9.504, de 30 de setembro de 1997. Estabelece normas para as eleições. Disponível em: < http://www.planalto.gov.br/ccivil_03/LEIS/L9504.htm >. Acesso em: 24 abr. 2016.

${ }^{58}$ BRASIL. Lei n. 9.096, de 19 de setembro de 1995. Dispõe sobre partidos políticos, regulamenta os arts. 17 e 14, $\S 3^{\circ}$, inciso V, da Constituição Federal. Disponível em: 〈http://www.planalto.gov.br/ccivil_03/leis/L9096.htm >. Acesso em: 24 abr. 2016.

${ }^{59}$ BRASIL. Supremo Tribunal Federal. Acórdão na Ação Direta de Inconstitucionalidade. ADI n. 4.650. Tribunal Pleno. Requerente: Conselho Federal da Ordem dos Advogados do Brasil - CFOAB. Intimados: Presidente da República e Congresso Nacional. Relator: Luiz Fux. Voto do Ministro Gilmar Mendes. Brasília, 17 de setembro de 2015. Disponível em: <http://www.stf.jus.br/portal/processo/verProcessoAndamento.asp?incidente=4136819 $>$. Acesso em: 24 abr. 2016.
} 
constantemente trazido à baila quando o cenário político se encontra em severo abalo e descrédito frente à sociedade.

A Ação Direta de Inconstitucionalidade n. 4.650 foi ajuizada em 5 de setembro de 2011 no Supremo Tribunal Federal (STF), e distribuída à relatoria do Ministro Luiz Fux, que atuou como relator até o julgamento final da ação. ${ }^{60}$ Cumpre ressaltar que Ação Direta de Inconstitucionalidade (ADI) é instrumento de controle concentrado da constitucionalidade de determinada norma. ${ }^{61}$

Concisamente, a ADI n. 4.650 apresentava três pedidos principais. Primeiro, que fossem declarados inconstitucionais os arts. 23, $\S 1^{\circ}$, incisos I e II; art. 24, e art. 81, caput, e $\S 1^{\circ}$, da Lei 9.504/97; além dos arts. 31, 38, inciso III, e 39, caput e § 5º da Lei 9.096/95; para que fosse vedada contribuição de pessoas jurídicas para financiamento de campanhas eleitorais. ${ }^{62}$ Também, que o Congresso Nacional fosse instado a editar legislação que estabelecesse limite per capta uniforme para doações de pessoa física a campanha eleitoral ou a partido político, em patamar baixo o suficiente para não comprometer excessivamente a igualdade nas eleições. ${ }^{63}$ Por fim, também fosse instado o Congresso Nacional a limitar, da mesma forma, o uso de recursos próprios pelos candidatos em campanha eleitoral. ${ }^{64}$

O voto do Ministro Luiz Fux, relator da ADI, trouxe argumentações que foram repetidas nos votos da maioria dos demais ministros, para que fossem declaradas inconstitucionais as doações por pessoas jurídicas a partidos e campanhas eleitorais. É possível destacar cinco argumentos, aqui apresentados como "pressupostos", que prevaleceram na referida decisão da Suprema Corte, ao averiguar se as doações de empresas promovem ou são prejudiciais ao Princípio Democrático:

\footnotetext{
${ }^{60}$ BRASIL. Supremo Tribunal Federal. Andamento Processual da ADI n. 4.650. Disponível em: <http://www.stf.jus.br/portal/processo/verProcessoAndamento.asp?incidente=4136819>. Acesso em: 3 out. 2016 ${ }^{61}$ BRASIL. Supremo Tribunal Federal. Glossário Jurídico. Disponível em:

<http://www.stf.jus.br/portal/glossario/verVerbete.asp?letra=A\&id=124>. Acesso em: 3 out. 2016.

${ }^{62}$ BRASIL. Supremo Tribunal Federal. Acórdão na Ação Direta de Inconstitucionalidade. ADI n. 4.650. Tribunal Pleno. Requerente: Conselho Federal da Ordem dos Advogados do Brasil - CFOAB. Intimados: Presidente da República e Congresso Nacional. Relator: Luiz Fux. Brasília, 17 de setembro de 2015. Disponível em: <http://www.stf.jus.br/portal/processo/verProcessoAndamento.asp?incidente=4136819 >. Acesso em: 24 abr. 2016.

${ }^{63}$ Ibidem.

64 Ibidem.
} 
(i) Incompatibilidade do exercício de direitos políticos com a natureza das pessoas jurídicas; 65

(ii) $\mathrm{O}$ direito de expressão de pessoas jurídicas não seria violado com a proibição de suas doações, porque, antes de expressar preferências políticas, as doações denotariam uma estratégia de empresas para estreitar relações com o poder público; 66

(iii) Haveria ofensa ao princípio da igualdade se autorizada doação por parte de outras pessoas jurídicas, mas vedadas as doações por entidades sem fim lucrativos e sindicatos, como anteriormente posto pela lei. ${ }^{67}$

(iv) A vedação de doações por pessoas jurídicas não dificultaria o custeio das campanhas eleitorais, uma vez que os partidos continuariam tendo acesso aos recursos do fundo partidário e à propaganda eleitoral gratuita, além de poderem contar com doações de pessoas físicas; 68

(v) Não mereceria prosperar a alegação de que a vedação de doações não impediria as pessoas jurídicas de influenciar o processo político, pois estas se valeriam de formas ilícitas; ressaltando que se faz necessária, como sempre, a preocupação com 0 fortalecimento de mecanismos de fiscalização; 69

Assim, o Ministro Luiz Fux julgou procedente o pedido de declaração de inconstitucionalidade dos dispositivos que autorizavam doações de pessoas jurídicas ao processo eleitoral; tendo, todavia, julgado improcedentes os pedidos acerca dos limites para doações de pessoas físicas e do uso de recursos próprios - o primeiro

\footnotetext{
${ }^{65}$ BRASIL. Supremo Tribunal Federal. Acórdão na Ação Direta de Inconstitucionalidade. ADI n. 4.650. Tribunal Pleno. Requerente: Conselho Federal da Ordem dos Advogados do Brasil - CFOAB. Intimados: Presidente da República e Congresso Nacional. Relator: Luiz Fux. Brasília, 17 de setembro de 2015. Disponível em: <http://www.stf.jus.br/portal/processo/verProcessoAndamento.asp?incidente=4136819 >. Acesso em: 24 abr. 2016.

66 Ibidem.

67 Ibidem.

68 Ibidem.

69 Ibidem.
} 
por entender ser uma opção política do legislador, e o segundo tendo como fundamento os princípios da cidadania, do pluralismo político e da liberdade de participação política. ${ }^{70}$

No dia 17 de setembro de 2015, o Tribunal Pleno, por maioria e nos termos do voto do Ministro Relator, julgou procedente em parte o pedido formulado na ADI para declarar a inconstitucionalidade dos dispositivos legais que autorizavam as contribuições de pessoas jurídicas às campanhas eleitorais, vencidos os Ministros Teori Zavascki, Celso de Mello e Gilmar Mendes, que deram interpretação nos termos do voto reajustado do Ministro Teori Zavascki. O Tribunal rejeitou a modulação dos efeitos da declaração de inconstitucionalidade e, consequentemente, a decisão seria aplicável às eleições de 2016 e seguintes, a partir da Sessão de Julgamento, independentemente da publicação do acórdão. ${ }^{71}$

Enquanto pendia o julgamento final da ADI n. 4.650, o Congresso Nacional elaborava o Projeto de Lei n. 5.735/2013, chamado de "quarta minirreforma eleitoral", que alterava a Lei de partidos políticos (Lei n. 9.096/95), Lei das eleições (Lei n. 9.505/97) e o Código Eleitoral (Lei n. 4.737/65). No que tange ao financiamento eleitoral, o projeto de lei autorizava doação de pessoas jurídicas, com a algumas limitações cumulativas: mantinha o limite de $2 \%$ do faturamento bruto da empresa no ano anterior à eleição; sendo que as doações totais não poderiam ultrapassar $\mathrm{R} \$$ 20.000.000,00 (vinte milhões de reais); e, ainda, as doações a um mesmo partido não poderiam ser superiores a $0,5 \%$ do faturamento bruto da empresa. ${ }^{72}$

A lei aprovada pelo Congresso Nacional no dia 9 de setembro de 2015 foi encaminhada à Presidente Dilma Rousseff, que a sancionou com vetos. ${ }^{73}$ Nota-se que no momento em que a Presidente apreciou a referida lei, o Supremo Tribunal Federal

\footnotetext{
${ }^{70}$ BRASIL. Supremo Tribunal Federal. Acórdão na Ação Direta de Inconstitucionalidade. ADI n. 4.650. Tribunal Pleno. Requerente: Conselho Federal da Ordem dos Advogados do Brasil - CFOAB. Intimados: Presidente da República e Congresso Nacional. Relator: Luiz Fux. Voto do Ministro Luiz Fux. Brasília, 17 de setembro de 2015. Disponível em: <http://www.stf.jus.br/portal/processo/verProcessoAndamento.asp?incidente=4136819>. Acesso em: 03 de out. 2016.

${ }^{71}$ Ibidem.

${ }^{72}$ BRASIL. Câmara dos Deputados. Câmara conclui votação da minirreforma eleitoral e mantém doação de empresas a partidos. Disponível em: <http://www2.camara.leg.br/camaranoticias/noticias/politica/495798camara-conclui-votacao-da-minirreforma-eleitoral-e-mantem-doacao-de-empresas-a-partidos.html>. Acesso em: 3 out. 2016.

${ }^{73}$ BRASIL. Lei $n$. 13.165, de 29 de setembro de 2015. Disponível em:

<http://pesquisa.in.gov.br/imprensa/jsp/visualiza/index.jsp?data=29/09/2015\&jornal=1000\&pagina=1\&totalArq uivos=32> . Acesso em:03 de out. 2016.
} 
acabara de pronunciar-se na ADI n. 4.650. Mesmo não tendo sido transitada em julgado a decisão, nem mesmo ainda publicada, a ex-Presidente Dilma Rousseff optou por vetar o dispositivo que autorizava doações de pessoas jurídicas, justificando com base na decisão do STF, que entendeu serem tais doações inconstitucionais. Assim foi sancionada a Lei n. 13.165, de 29 de setembro de 2015, chamada de "minirreforma eleitoral".

Desta feita, o financiamento eleitoral no Brasil atualmente se dá da seguinte forma: financiamento público, pelo Fundo Partidário e pela propaganda eleitoral gratuita; ${ }^{74}$ e financiamento privado, por pessoas físicas. Nota-se que os pedidos da ADI n. 4.650 relativos às pessoas físicas não foram previstos na Lei n. 13.165/15. Assim, não foi criado limite per capita para as contribuições de pessoas físicas, tendo sido mantido o teto de $10 \%$ (dez por cento) do rendimento bruto do ano anterior e aumentado o valor máximo para doação de bem estimável em dinheiro, para $R \$$ $80.000,00$ (oitenta mil reais). Além disso, a nova legislação autoriza expressamente o uso de recursos próprios do candidato para financiar sua campanha, sem limite fixo, exceto o teto de gastos da campanha a ser estabelecido. ${ }^{75}$

Diante o exposto, percebe-se que o assunto provocou mobilização e envolvimento dos três poderes da República. Atualmente, tramita no Congresso Nacional um Projeto de Emenda à Constituição (PEC 113A/2015) de iniciativa da Câmara dos Deputados que, dentre outras alterações, pretende autorizar contribuições de pessoas jurídicas a partidos políticos, e de pessoas físicas apenas a candidatos, nos limites da lei. ${ }^{76}$ Essa alteração no texto constitucional superaria a decisão do Supremo Tribunal Federal na ADI n. 4.650 e, mais uma vez, o modelo de financiamento eleitoral seria revertido.

Há, por outro lado, certa resignação por parte dos parlamentares, e o Congresso Nacional vem discutindo uma reforma política que faria mudanças no

\footnotetext{
${ }^{74}$ BRASIL. Lei n. 9.096, de 19 de setembro de 1995. Dispõe sobre partidos políticos, regulamenta os arts. 17 e 14 , $\S 3^{\circ}$, inciso V, da Constituição Federal. Disponível em: <http://www.planalto.gov.br/ccivil_03/leis/L9096.htm >. Acesso em: 24 abr. 2016.

${ }^{75}$ BRASIL. Lei $n$. 9.504, de 30 de setembro de 1997. Estabelece normas para as eleições. Disponível em: < http://www.planalto.gov.br/ccivil_03/LEIS/L9504.htm >. Acesso em: 24 abr. 2016.

76 BRASIL. Proposta de Emenda à Constituição $n^{o} 113 A$, de 2015. Disponível em: $<$ http://www.senado.gov.br/atividade/materia/getPDF.asp?t=184928\&tp=1>. Acesso em: 10 de nov. 2016.
} 
sistema eleitoral brasileiro, a fim de viabilizar as campanhas eleitorais conforme o novo modelo proposto com a Minirreforma Eleitoral de 2015.

\subsection{Financiamento Eleitoral na França}

A França é uma democracia representativa, que se organiza sob o sistema semipresidencialista de governo. No semipresidencialismo francês, o Presidente da República (chefe de Estado) e o Poder Legislativo são independentes, mas o Presidente nomeia um Primeiro-Ministro (chefe de governo) que, por sua vez, é responsável perante o Legislativo pela determinação e execução de determinadas políticas e pelos serviços administrativos. Assim, a Constituição francesa reserva atribuições muito maiores ao Presidente do que os regimes parlamentaristas costumam reservar. ${ }^{77}$

O Presidente da República francesa é eleito, em eleições diretas, para um mandato de cinco anos, com a possibilidade de reeleição. Para isso, precisa ter maioria absoluta no primeiro turno, caso contrário, os dois candidatos mais votados seguem para o segundo turno; em formato similar ao brasileiro. Já o Poder Legislativo é dividido entre a Assembleia Nacional e o Senado. Os Deputados (membros da Assembleia Nacional), que somam 577, são escolhidos por eleições diretas e universais para mandatos também de cinco anos. O primeiro turno das eleições funciona de forma similar à presidencial, sendo descartados no segundo turno os candidatos que não obtiverem no mínimo $12,5 \%$ dos votos. ${ }^{78}$ Os Senadores, por suas vezes, são apontados por um colégio eleitoral, ou seja, são eleitos por sufrágio indireto. ${ }^{79}$

Apesar de os cidadãos franceses terem a sensação de viver constantemente em campanha eleitoral, esta tem duração oficial curta. Nas eleições presidenciais, a campanha eleitoral compreende as duas semanas anteriores às votações do primeiro turno e a semana que antecede o segundo turno. Para as

\footnotetext{
${ }^{77}$ BANDEIRA, Regina Maria Groba. Sistemas de governo no Brasil, na França e nos Estados Unidos da América. Câmara dos Deputados, Brasília, fev. 2015, p. 10

${ }^{78}$ LIBRARY OF CONGRESS. Campaign finance: France. Disponível em:

<https://www.loc.gov/law/help/campaign-finance/france.php>. Acesso em: 20 dez. 2016.

${ }^{79}$ REINER, Lúcio. França: Ética e transparência na política. Brasília: Câmara dos Deputados, Brasília, set. 2001, p.4
} 
eleições de Deputados, são os vinte dias anteriores às eleições do primeiro turno. A França possui um Código Eleitoral e as datas das eleições são marcadas por decreto. ${ }^{80}$

Até a década de 1980, os custos das campanhas eleitorais na França vinham subindo significativamente com o uso de mecanismos cada vez mais sofisticados e de diversos meios de comunicação. Além disso, alguns escândalos envolvendo fontes de financiamento eleitoral chocaram o país. Por essas razões, em 1988, foram realizadas alterações na legislação eleitoral francesa. Entendia-se que a matéria estava muito atrasada em relação a outros países europeus. Por exemplo, a França criou uma regulação sólida sobre financiamento eleitoral vinte anos mais tarde que a Alemanha e os países escandinavos. ${ }^{81}$

Diante do cenário político mencionado, de altos gastos e escândalos eleitorais, em março de 1988 foram promulgadas duas leis, quais sejam, a lei orgânica 88-226 e a lei 88-227, visando aumentar a transparência na vida política francesa. Essas duas leis foram alteradas e complementadas pela lei 90-55, de 15 de janeiro de 1990, tratando dos limites das despesas eleitorais e da prestação de contas sobre o custeio das campanhas. ${ }^{82}$

Em 1995, o Poder Público decidiu romper por completo a relação entre o financiamento eleitoral e pessoas jurídicas, notadamente, as empresas. A partir de então, as despesas eleitorais passaram a ter um teto para assegurar a equidade entre os candidatos, independentemente de seus recursos pessoais. Fixou-se também uma série de penalidades para eventuais irregularidades. Além disso, as contas eleitorais passaram a ser submetidas a uma autoridade administrativa independente, chamada Commission nationale descomptes de campagne et des financements politiques (CN CCFP), sob controle do juiz de eleição (Conseil constitutionnel pour l'élection présidentielle et les

\footnotetext{
${ }^{80}$ LIBRARY OF CONGRESS. Campaign finance: France. Disponível em:

<https://www.loc.gov/law/help/campaign-finance/france.php>. Acesso em: 20 dez. 2016.

${ }^{81}$ Ibidem.

${ }^{82}$ Ibidem.
} 
élections législatives et juge administratif pour les autres élections) ${ }^{83}$ para garantir a aplicação das referidas alterações legais. ${ }^{84}$

Desta feita, pessoas jurídicas são proibidas de contribuir direta (oferecendo dinheiro) ou indiretamente (favorecendo de qualquer forma) para o financiamento de campanhas de candidatos ou partidos políticos. Cumpre ressalvar que nem toda pessoa jurídica é proibida de colaborar, pois partidos e grupos políticos podem, sim, contribuir para o financiamento eleitoral.

Com a vedação da participação de empresas, o financiamento público precisou compensar o ônus que tal restrição de dinheiro impõe sobre as campanhas. ${ }^{85}$ Optou-se, então, por fortalecer o financiamento eleitoral público na França. O financiamento público pode se dar de forma direta ou indireta.

O financiamento público direto se dá com: (i) o reembolso que o Estado francês oferece, após a eleição, aos candidatos a Deputado e a Presidente (visto que os Senadores são eleitos por sufrágio indireto) que conquistam mais de 5\% (cinco por cento) dos votos da circunscrição (das maiores que nove mil habitantes) em valor equivalente a 47,5 \% (quarenta e sete e meio por cento) do limite estabelecido para as despesas; desde que suas contas de campanha sejam aprovadas; e (ii) a ajuda financeira concedida pelo Estado aos partidos políticos. A despesa pública com essa ajuda deve ter previsão anual na lei orçamentária. Em 2013, o valor subiu para $€ 76.260 .000,00$ (setenta e seis milhões e duzentos e sessenta mil euros); mas em 2014 baixou em 10\% (dez por cento), como medida econômica para melhorar as finanças públicas, somando $€ 68.640 .000,00$ (sessenta e oito milhões e seiscentos e quarenta mil euros). Esse valor é repartido pelos partidos políticos por dois fatores: a primeira metade do valor é repartida em razão dos resultados do primeiro turno das últimas eleições legislativas - com algumas exceções, como para garantir igualdade de gêneros; e, na segunda metade, apenas são considerados os partidos aptos na

\footnotetext{
${ }^{83}$ ASSEMBLÉE NATIONALE. Fiche de synthèse $n$. 15: Le financement de la vie politique, partis et campagnes électorales. Disponível em: < http://www2.assemblee-nationale.fr/decouvrir-1-assemblee/role-et-pouvoirs-de-1assemblee-nationale/le-depute/le-financement-de-la-vie-politique-partis-et-campagnes-electorales>. Acesso em: 20 dez. 2016.

${ }^{84}$ LIBRARY OF CONGRESS. Campaign finance: France. Disponível em:

<https://www.loc.gov/law/help/campaign-finance/france.php>. Acesso em: 20 dez. 2016.

${ }^{85}$ Ibidem.
} 
primeira metade, sendo dividida entre os partidos na proporção do número de seus Deputados no Parlamento. ${ }^{86}$

Já a o financiamento público indireto pode se dar pelo que os franceses chamam de "direito de antena", que é a concessão de horário em canais de rádio e televisão públicos oferecida para grupos políticos com representação na Assembleia Nacional ou no Senado, ${ }^{87}$ sendo que os candidatos dispõem do mesmo tempo de exposição. O Estado também garante que canais de rádio e televisão organizem programas para que os candidatos, de forma igualitária, exponham suas ideias durante o período eleitoral oficial. ${ }^{88}$ Interessante pontuar que, nos seis meses anteriores às eleições, é vedado o uso de propaganda paga, por qualquer meio audiovisual, como afixar pôsteres ou qualquer material, distribuir panfletos, postais ou telefonemas. Ainda, outra forma como o Estado francês ajuda a custear eleições é através da concessão de alívio fiscal a partidos políticos, como na locação de imóveis. ${ }^{89}$

O financiamento eleitoral privado, por sua vez, representa uma parcela pequena do financiamento total, mas a importância pode variar de um partido para outro. Isso porque os próprios partidos políticos podem doar recursos para campanhas; e essas doações variam visto que os partidos podem dispor de outras receitas privadas, através de atividade econômica própria. ${ }^{90}$ Não há limite de valor que os partidos políticos podem injetar na campanha de um candidato, desde que se respeite o valor fixado como teto dos gastos de campanha. Também não há limite para as doações de recursos próprios que o candidato pode injetar em sua campanha; contanto que respeite mencionado teto de gastos. ${ }^{91}$

Em suma, o financiamento privado se dá apenas por partidos e grupos políticos ou pessoas físicas. ${ }^{92}$ As contribuições voluntárias de pessoas físicas foram

\footnotetext{
${ }^{86}$ ASSEMBLÉE NATIONALE. Fiche de synthèse $n$. 15: Le financement de la vie politique, partis et campagnes électorales. Disponível em: < http://www2.assemblee-nationale.fr/decouvrir-1-assemblee/role-et-pouvoirs-de-1assemblee-nationale/le-depute/le-financement-de-la-vie-politique-partis-et-campagnes-electorales $>$. Acesso em: 20 dez. 2016.

${ }^{87}$ Ibidem.

${ }^{88}$ LIBRARY OF CONGRESS. Campaign finance: France. Disponível em:

<https://www.loc.gov/law/help/campaign-finance/france.php>. Acesso em: 20 dez. 2016.

${ }^{89}$ ASSEMBLÉE NATIONALE. op. cit.

${ }^{90}$ Ibidem.

${ }^{91}$ LIBRARY OF CONGRESS, op. cit.

${ }^{92}$ ASSEMBLÉE NATIONALE, op. cit.
} 
autorizadas, com teto fixado pela lei 88-227, de 11 março de 1988. No entanto, essas doações de pessoas físicas são autorizadas a partir do ano anterior às eleições até o dia da votação. Em contrapartida, provando suas contribuições, as pessoas físicas podem receber crédito tributário de até 66\% (sessenta e seis por cento) do valor doado, desde que o crédito não ultrapasse $20 \%$ (vinte por cento) do valor por elas devido ao Fisco.

As doações de pessoas físicas podem ser diferenciadas em dois grupos: doações de até $€ 150,00$ (cento e cinquenta euros), chamadas "cash contributions", 93 e as superiores a $€ 150,00$ (cento e cinquenta) euros, com o limite de $€ 7.500,00$ (sete mil e quinhentos euros) por pessoa física, e por ano. ${ }^{94}$ As últimas devem ser feitas por cheque ou online, identificando devidamente o doador. Ressalta-se ainda que o valor total de "cash contributions" angariados pelo candidato não pode ultrapassar $20 \%$ do valor de suas despesas totais na campanha. ${ }^{95}$ Diante de toda a regulação explanada, o financiamento privado oriundo de pessoa física tem pouca expressão nas eleições francesas. ${ }^{96}$

Estados e pessoas jurídicas estrangeiros não podem participar do financiamento eleitoral na França, muito embora não haja previsão expressa que vede a participação de pessoa física estrangeira. ${ }^{97}$

Além das regras legais de quem pode doar, e quanto pode doar, a campanha ainda deve respeitar o mencionado teto de gastos eleitorais. $O$ teto de gastos para eleições presidenciais é fixado em $€ 16.851 .000,00$ (dezesseis milhões e oitocentos e cinquenta e um mil euros) para cada candidato do primeiro turno, e em $€ 22.509 .000,00$ (vinte e dois milhões e quinhentos e nove mil euros) por candidato do

\footnotetext{
93 ASSEMBLÉE NATIONALE. Fiche de synthèse n. 15: Le financement de la vie politique, partis et campagnes électorales. Disponível em: < http://www2.assemblee-nationale.fr/decouvrir-1-assemblee/role-et-pouvoirs-de-1assemblee-nationale/le-depute/le-financement-de-la-vie-politique-partis-et-campagnes-electorales>. Acesso em: 20 dez. 2016.

${ }^{94}$ FRANÇA. Lei n. 2013-907, de 11 de outubro de 2013. Dispões sobre a transparência na vida pública. Paris,2013. Disponível em:

<https://www.legifrance.gouv.fr/affichTexte.do?cidTexte=JORFTEXT000028056315>. Acesso em: 20 dez. 2016

${ }^{95}$ LIBRARY OF CONGRESS. Campaign finance: France. Disponível em:

<https://www.loc.gov/law/help/campaign-finance/france.php>. Acesso em: 20 dez. 2016.

${ }^{96}$ ASSEMBLÉE NATIONALE. op. cit.

${ }^{97}$ Ibidem.
} 
segundo turno. ${ }^{98}$ Já para as eleições de deputados, o limite é calculado através do número de habitantes do território do eleitorado. $O$ teto dos gastos para campanha de Deputado é de $€ 38.000,00$ (trinta e oito mil euros) por candidato, podendo ser acrescido de $€ 0,15$ (quinze centavos de euro) por habitante da zona eleitoral (multiplicado pelo coeficiente 1.18). ${ }^{99} \mathrm{Em} 2011$, com o intuito de simplificar a legislação eleitoral, determinou-se que o teto das despesas fosse fixado com a correção da inflação a cada ano. No entanto, em 2012, aprovou-se uma lei congelando o limite de gastos eleitorais até que as contas públicas retornassem ao equilíbrio. ${ }^{100}$

$\mathrm{Na}$ França, todo candidato nomeia um mandatário, seja pessoa física ou associação de financiamento eleitoral, de forma que cabe a estes recolher receitas e pagar despesas; estando o candidato impedido de manejar diretamente o dinheiro de financiamento de sua campanha. Abre-se então uma conta eleitoral, que, caso o candidato tenha ao menos $1 \%$ dos votos, deverá ser submetida à análise do Conselho (CNCCFP), analisada por juiz eleitoral que averiguará qualquer irregularidade. ${ }^{101}$

Desta feita, todas as prestações de contas das campanhas eleitorais são devidas por seus mandatários, e as contas devem ser encaminhadas à autoridade competente, CNCCFP, até a nona sexta-feira seguinte às votações. A CNCCFP tem então seis meses para analisar as contas; e ao fim pode: aprova-las; aprova-las com ressalvas ou rejeita-las por violar o Código Eleitoral. Neste último caso, a Comissão notifica o Procurador Geral ou juiz competente. ${ }^{102}$ Por outro lado, se as contas são aprovadas e o candidato conta com no mínimo 5\% (cinco por cento) dos votos no

\footnotetext{
${ }^{98}$ FRANÇA. Vie publique au coeur du débat public. Comment devient-on président de la République? Paris, 2017. Disponível em: < http://www.vie-publique.fr/decouverte-institutions/institutions/fonctionnement/presidentrepublique/comment/comment-est-financee-campagne-electorale.html>. Acesso em: 18 mar. 2017.

${ }^{99}$ FRANÇA. Article L52-11 modifié par LOI n²015-1268 du 14 octobre 2015 - art. 38. Disponível em: $<$ https://www.legifrance.gouv.fr/affichCodeArticle.do?cidTexte=LEGITEXT000006070239\&idArticle=LEGIA RTI000031325083\&dateTexte=20170319>. Acesso em: 18 mar. 2017; LIBRARY OF CONGRESS. Campaign finance: France. Disponível em: <https://www.loc.gov/law/help/campaign-finance/france.php>. Acesso em: 20 dez. 2016

${ }^{100}$ ASSEMBLÉE NATIONALE. Fiche de synthèse n. 15: Le financement de la vie politique, partis et campagnes électorales. Disponível em: < http://www2.assemblee-nationale.fr/decouvrir-1-assemblee/role-et-pouvoirs-de-lassemblee-nationale/le-depute/le-financement-de-la-vie-politique-partis-et-campagnes-electorales $>$. Acesso em: 20 dez. 2016.

101 ASSEMBLÉE NATIONALE. Fiche de synthèse $n$. 1: Le financement de la vie politique, partis et campagnes électorales. Disponível em: < http://www2.assemblee-nationale.fr/decouvrir-1-assemblee/role-et-pouvoirs-de-1assemblee-nationale/le-depute/le-financement-de-la-vie-politique-partis-et-campagnes-electorales $>$. Acesso em: 20 dez. 2016.

102 Ibidem.
} 
primeiro turno, este poderá receber reembolso do Estado em até 47,5 \% (quarenta e sete e meio por cento) de suas despesas (financiamento público direto). ${ }^{103}$

A CNCCPF é composta por nove membros, nomeados por decreto para mandato de cinco anos. Três deles vêm do Conselho de Estado (corte suprema para matéria administrativa) ${ }^{104}$, três da Corte de Cassação (corte suprema para matéria judicial $)^{105}$ e, por fim, três do Tribunal de Contas. Fora isso, a Comissão conta com secretariado cedido por outros ministérios e aproximadamente 160 juízes. ${ }^{106}$

A legislação francesa também impõe transparência com relação ao patrimônio dos eleitos, com o fim de evitar enriquecimento ilícito. Os servidores de determinados cargos públicos devem encaminhar uma "declaração de interesses", que será analisada pela "Alta Autoridade de Transparência da Vida Pública" (Haute Autorité pour la Transparence de la Vie Publique). Assim, o patrimônio dos eleitos deve ser declarado no começo e ao fim do mandato. ${ }^{107}$

As sanções penais para a falsidade da referida declaração ou omissão de parte substancial do patrimônio são severas: pena de 3 anos de prisão, e 45mil euros de multa (sanção que foi reforçada em 2013); além de pena complementar de perda dos direitos civis e do exercício de função pública. ${ }^{108} \mathrm{E}$ cabe destacar que as penalidades são as mesmas para aqueles contribuíram para campanhas eleitorais descumprindo as regras eleitorais. ${ }^{109}$

Nota-se que a legislação francesa sobre financiamento eleitoral é bemintencionada, no sentido de expressar o sufrágio, tentando igualizar, na medida do possível, as condições de participação no pleito eleitoral. Isso acontece porque o financiamento eleitoral na França é majoritariamente público. Segundo Casas-Zamora

\footnotetext{
${ }^{103}$ LIBRARY OF CONGRESS. Campaign finance: France. Disponível em: <https://www.loc.gov/law/help/campaign-finance/france.php>. Acesso em: 20 dez. 2016.

104 FRANÇA. Le conséil d'Etat et la jurisdition administrative. Disponível em: <http://www.conseiletat.fr/Conseil-d-Etat/Missions>. Acesso em: 20 dez. 2016

${ }^{105}$ FRANÇA. Cour de Cassation. Disponível em: <https://www.courdecassation.fr/>. Acesso em: 20 dez. 2016. ${ }^{106}$ LIBRARY OF CONGRESS, op. cit.

${ }^{107}$ ASSEMBLÉE NATIONALE. Fiche de synthèse $n$. 1 : Le financement de la vie politique, partis et campagnes électorales. Disponível em: < http://www2.assemblee-nationale.fr/decouvrir-1-assemblee/role-et-pouvoirs-de-1assemblee-nationale/le-depute/le-financement-de-la-vie-politique-partis-et-campagnes-electorales>. Acesso em: 20 dez. 2016.

108 ASSEMBLÉE NATIONALE. Fiche de synthèse $n$. 15: Le financement de la vie politique, partis et campagnes électorales. Disponível em: < http://www2.assemblee-nationale.fr/decouvrir-1-assemblee/role-et-pouvoirs-de-1assemblee-nationale/le-depute/le-financement-de-la-vie-politique-partis-et-campagnes-electorales>. Acesso em: 20 dez. 2016.

${ }^{109}$ LIBRARY OF CONGRESS. op. cit.
} 
e Zovatto, em "The cost of democracy", o financiamento público costuma ter efeito "equalizador", de modo a dar chance a partidos pequenos e menos próximos do empresariado. ${ }^{110}$

Nesse mesmo sentido, as regras eleitorais francesas são rígidas e bem definidas na tentativa de afastar a participação de empresas. Para Casas-Zamora e Zovatto, o financiamento eleitoral público é capaz de reduzir a participação de grandes empresas no financiamento eleitoral; mas isso se dá mais por uma organização institucional, somada à regulação de fatores como: campanhas curtas, publicidade limitada, incentivo fiscal para doações de pessoas físicas; do que propriamente pela quantidade de dinheiro oferecido pelo Estado como subsídio. ${ }^{111}$

O subsídio público pode ser oferecido de diversas maneiras e pode ter peso maior ou menor no financiamento eleitoral. Bradley A. Smith ilustra bem a questão do financiamento público de campanhas: defender o financiamento eleitoral público é o mesmo que afirmar gostar de esportes. De quais esportes? Futebol? Caiaque? Xadrez? ${ }^{112}$

A legislação francesa sobre financiamento eleitoral opta por vedar contribuições de pessoas jurídicas, com exceção dos partidos políticos, e garante o predomínio do financiamento público das campanhas eleitorais. Muito embora o Estado francês encabece o topo da lista de países que mais subsidiam os gastos eleitorais, ${ }^{113}$ o generoso financiamento público de campanhas não é capaz de conter a ocorrência de escândalos envolvendo irregularidades no financiamento eleitoral. ${ }^{114}$ Por exemplo, o ex-presidente francês Nicolas Sarkozy teve suas contas rejeitadas, sendo acusado de "caixa dois", por usar uma pessoa jurídica para esconder recursos que foram gastos em sua campanha, em 2012. O ex-presidente teria se valido de cerca de $€ 18.000 .000,00$ (dezoito milhões de euros) não declarados em suas contas. ${ }^{115}$

\footnotetext{
${ }^{110}$ CASAS-ZAMORA, Kevin; ZOVATTO, Daniel. The Cost of Democracy: essays on Political Finance in Latin America. Costa Rica: IDEA, 2016, p. 35

111 Ibidem, p.35.

${ }^{112}$ SMITH, Bradley. Unfree Speech: The folly of campaign finance reform. Princeton: Princeton University Press, 2001, p. 89

113 CASAS-ZAMORA, Kevin; ZOVATTO, Daniel. op. cit., p.33

114 Ibidem, p.35

115 BBC. Nicolas Sarkozy: A patchwork of ex-president's legal woes. 2017. Disponível em: <http://www.bbc.com/news/world-europe-28103690>. Acesso em: 27 jul. 2017
} 
O regulamento rígido do financiamento eleitoral traz como consequência uma necessidade de fiscalização mais atenciosa das contas eleitorais. Assim, muito se discute sobre a capacidade de fiscalização do sistema eleitoral francês para apurar irregularidades no financiamento de campanhas. Por exemplo, aponta-se que a CNCCPF teria de cuidar sozinha de tarefas muito complexas, como verificar se todas as doações de pessoas físicas não ultrapassaram o valor permitido por ano. A tarefa torna-se ainda mais complicada quando os partidos não enviam as listas de seus doadores. Em 2016, apenas um terço dos partidos declararam suas listas de doadores, sendo que, destes, apenas metade o fez no formato exigido pela CNCCPF. A própria Comissão afirma ser necessária a criação de algum tipo de sanção para os partidos que não cumprem a exigência - o que, até o momento, não foi criado. ${ }^{116}$

$\mathrm{Na}$ França, a legislação eleitoral determina que os diversos candidatos devem receber as mesmas condições de tratamento pelo Poder Público; o que significa dizer, por exemplo, que a todos candidatos deve ser concedida uma exposição mínima e um tempo mínimo em rádio ou televisão. ${ }^{117}$ Apesar de, à primeira vista, entender-se que uma tentativa de equalização de condições dos candidatos deve ser absolutamente benéfica ao processo democrático, há que se considerar também os contras de tal tentativa. Para ilustrar, como resultado disso, em 2007, quatro candidatos, que somados obtiveram $4,1 \%$ dos votos, tiveram direito a um terço do tempo disponível em rádio e televisão durante as duas semanas anteriores às eleições. ${ }^{118}$

Nesse mesmo sentido, a intenção de conceder o mesmo tempo a todos os candidatos na propaganda eleitoral gratuita pode tornar o debate mais superficial, pois os candidatos não teriam tempo de apresentar detalhadamente suas propostas e aprofundar suas visões sobre temas importantes, como reformas estruturais, economia, globalização, e acabam focando em aspectos mais triviais, como a

\footnotetext{
116 LE MONDE. D'où vient le financement des partis politiques? Paris, 2017. Disponível em: <http://www.lemonde.fr/les-decodeurs/article/2017/02/10/d-ou-vient-le-financement-des-partispolitiques_5077918_4355770.html?xtmc=financement_des_partis_politiques\&xtcr=2>. Acesso em: 16 mar. 2017.

${ }^{117}$ FRANÇA. Vie publique au coeur du débat public. Comment devient-on président de la République? Paris, 2017. Disponível em: < http://www.vie-publique.fr/decouverte-institutions/institutions/fonctionnement/presidentrepublique/comment/comment-deroule-campagne-electorale.html>. Acesso em: 18 mar. 2017.

${ }^{118}$ MEUNIER, Sophie. The French presidency is a bargain. Disponível em:

<http://www.huffingtonpost.com/sophie-meunier/france-election-laws_b_1438456.html>. Acesso em 20 mar. 2017
} 
personalidade do candidato. Com isso, saem perdendo os eleitores. Assim, o financiamento público e a legislação eleitoral francesa, que tenta dar igualdade de condições aos candidatos, podem provocar efeitos também danosos à democracia. ${ }^{119}$

Por mais complexo e, por vezes, defeituoso que o financiamento eleitoral na França possa parecer, o debate político-jurídico não parece caminhar no sentido de aceitar doações de pessoas jurídicas. A opinião pública parece estar mais preocupada em corrigir as imperfeições do processo eleitoral do que em mudar radicalmente a legislação.

\subsection{Análise dos pressupostos adotados na ADI n. 4.650/2015}

Como já explanado no trabalho, o Supremo Tribunal Federal julgou, na ADI n. 4.650, inconstitucionais as doações de pessoas jurídicas às campanhas eleitorais; e nesse julgamento, os ilustres ministros adotaram cinco importantes argumentos. $O$ resultado do julgamento provocou mudanças na forma de financiar campanhas eleitorais e aproximou o modelo de financiamento eleitoral brasileiro ao modelo há muito estipulado na França. Portanto, vejamos como os cinco pressupostos adotados no julgamento da Supremo Corte brasileira são tratados na legislação francesa.

(i) Incompatibilidade do exercício de direitos políticos com a natureza das pessoas jurídicas: ${ }^{120}$

Para José Afonso da Silva, direitos políticos formam um "conjunto de normas legais permanentes que viabilizam o direito democrático de participação do povo no governo por meio de representantes". ${ }^{121}$ Assim, direitos políticos, como o de

\footnotetext{
${ }^{119}$ MEUNIER, Sophie. The French presidency is a bargain. Disponível em: $<$ http://www.huffingtonpost.com/sophie-meunier/france-election-laws_b_1438456.html>. Acesso em 20 mar. 2017.

${ }^{120}$ BRASIL. Supremo Tribunal Federal. Acórdão na Ação Direta de Inconstitucionalidade. ADI n. 4.650. Tribunal Pleno. Requerente: Conselho Federal da Ordem dos Advogados do Brasil - CFOAB. Intimados: Presidente da República e Congresso Nacional. Relator: Luiz Fux. Voto do Ministro Luiz Fux. Brasília, 17 de setembro de 2015. Disponível em: <http://www.stf.jus.br/portal/processo/verProcessoAndamento.asp?incidente=4136819 >. Acesso em: 24 abr. 2016.

${ }^{121}$ SILVA, José Afonso da. Curso de Direito Constitucional Positivo. 25. ed. São Paulo: Malheiros Editores, 2005. p. 344
} 
votar e de ser votado, são conferidos, no Brasil' ${ }^{122}$ e na França, aos cidadãos. ${ }^{123}$ Cidadãos são necessariamente pessoas físicas, de modo que, pessoas jurídicas não têm direitos políticos em ambos os países.

Por conseguinte, argumenta-se que por não gozarem de direitos políticos, as pessoas jurídicas não deveriam deter instrumentos para influenciar os resultados das eleições - por exemplo, por meio do financiamento eleitoral. ${ }^{124}$ Assim, pessoas jurídicas deveriam ser vedadas no financiamento eleitoral para que os representantes fossem eleitos pelos cidadãos, a quem são reconhecidos direitos políticos. ${ }^{125}$ Afinal, uma democracia representativa deveria ser pautada pela vontade popular. ${ }^{126}$

Esse argumento prevaleceu no recente julgamento do Supremo Tribunal Federal na ADI n. 4.650/2015, e também é adotado na França. Na França, além de não se reconhecer direitos políticos às pessoas jurídicas, a intervenção destas pessoas no financiamento de campanhas eleitorais não é permitida com a intenção de enfraquecer a ligação entre o poder econômico e o poder político. ${ }^{127}$

De fato, diversas democracias na Europa Ocidental optaram por vedar doações de pessoas jurídicas no financiamento eleitoral; ${ }^{128}$ de forma que 0 pressuposto adotado na decisão do STF está em consonância com diversas outras democracias consolidadas, entre elas, a França, ao vislumbrar uma incompatibilidade entre a capacidade de pessoas jurídicas de influenciar o pleito eleitoral e o fato destas não gozarem de direitos políticos.

(ii) O direito de expressão de pessoas jurídicas não seria violado com a proibição de suas doações, porque, antes de expressar preferências políticas, as doações denotariam uma

\footnotetext{
${ }^{122}$ SILVA, José Afonso da. Curso de Direito Constitucional Positivo. 25. ed. São Paulo: Malheiros Editores, 2005. p. 346

${ }^{123}$ FRANÇA. Vie publique au coeur du débat public. Quel est le statut juridique d'um citoyen? 2013. Disponível em: < http://www.vie-publique.fr/decouverte-institutions/citoyen/citoyennete/definition/definir/quel-est-statutjuridique-citoyen.html >. Acesso em 27 jul. 2017

${ }^{124}$ XAVIER, Allan Ferreira. O financimento de campanha e sua influência na representação. Brasília: Vestnik, 2014. p. 64

125 Ibidem. p. 64

${ }^{126}$ DALARI, Dalmo de Abreu. Elementos da teoria geral do Estado. 2.ed., São Paulo: Saraiva, 2012. p. 56

${ }^{127}$ LIBRARY OF CONGRESS. Campaign finance: France. Disponível em:

<https://www.loc.gov/law/help/campaign-finance/france.php>. Acesso em: 20 dez. 2016.

${ }^{128}$ CASAS-ZAMORA, Kevin; ZOVATTO, Daniel. The Cost of Democracy: essays on Political Finance in Latin America. Costa Rica: IDEA, 2016, p. 28
} 
estratégia das empresas para estreitar relações com o poder público; ${ }^{129}$

$\mathrm{Na}$ França, o direito de expressão de pessoas jurídicas, no que tange ao debate político, é mitigado, pois estas pessoas não podem expressar suas preferências doando dinheiro a campanhas e partidos políticos. Isso se deve à forma como o país encara a relação entre dinheiro e política. A França regula o pleito eleitoral de forma a tornar a influência do dinheiro menos relevante, a fim de oferecer certa paridade de armas entre os candidatos e, consequentemente, obter resultados eleitorais mais justos. ${ }^{130}$

Como contraponto, há outras democracias consolidadas que operam de forma diferente e privilegiam a liberdade de expressão, sendo os Estados Unidos o mais notório delas. A Suprema Corte americana entende que o dinheiro que é gasto para fins eleitorais, mas de forma desvinculada a campanhas ou partidos - chamados "gastos independentes" - não implica em risco de corrupção algum; de modo que o Estado não poderia restringir ou vedar tais gastos, pois estes seriam um exercício da liberdade de expressão. ${ }^{131}$

Percebe-se que a França, e atualmente o Brasil, seguem na contramão do que é proposto nos Estados Unidos. A legislação francesa preocupa-se em regular detalhadamente quem pode gastar, quanto e quando pode ser gasto. No entanto, apesar de bem-intencionada, é possível fazer algumas críticas à regulação do financiamento eleitoral, quando excessiva. A França é um país de forte cultura política, com história política singular e que evidentemente não padece dos mesmos problemas sociais que o Brasil. Assim, há que se atentar que uma demasiada regulação do financiamento eleitoral, somada a rígidas regras para a propaganda eleitoral, no Brasil, pode ter intenções paternalistas e pode promover uma assepsia

\footnotetext{
${ }^{129}$ BRASIL. Supremo Tribunal Federal. Acórdão na Ação Direta de Inconstitucionalidade. ADI n. 4.650. Tribunal Pleno. Requerente: Conselho Federal da Ordem dos Advogados do Brasil - CFOAB. Intimados: Presidente da República e Congresso Nacional. Relator: Luiz Fux. Voto do Ministro Luiz Fux. Brasília, 17 de setembro de 2015. Disponível em: <http://www.stf.jus.br/portal/processo/verProcessoAndamento.asp?incidente=4136819>. Acesso em: 24 abr. 2016.

${ }^{130}$ KUHNER, Timothy K. Plutocracy and partyocracy. Rev. Const. Stud. n.1, v.21, 2016, p. 121

${ }^{131}$ KANG, Michael S. The end of Campaign Finance Law. Virginia Law Review, Charlottesville, v. 98, n. 1, mar. 2012, p. 4
} 
política, distanciando a sociedade da política e desencorajando a participação popular. ${ }^{132}$

Feita essa ressalva, é possível notar que a França não garante direito de expressão às pessoas jurídicas no debate político, como fazem os Estados Unidos, por exemplo; mas, mesmo estabelecendo regras de como a propaganda eleitoral pode ser financiada e promovida, a regulação eleitoral francesa, em si, não provoca um distanciamento da sociedade para com a política no país.

(iii) A vedação de doações por pessoas jurídicas não dificultaria o custeio das campanhas eleitorais, uma vez que os partidos continuariam tendo acesso aos recursos do fundo partidário e à propaganda eleitoral gratuita, além de poderem contar com doações de pessoas físicas; ${ }^{133}$

Como adiantado no tópico anterior deste capítulo, assim como o Brasil, a França conta com recursos públicos para a viabilização do custeio das eleições, além de oferecer espaços de rádio e televisão para propaganda eleitoral gratuita aos partidos. Ainda, as campanhas podem contar com recursos privados oriundos de doações de pessoas físicas. Assim, nota-se que, em regras gerais, o formato de financiamento eleitoral na França se assemelha em muito ao formato adotado no Brasil após o julgamento da ADI estudada e a posterior Minirreforma Eleitoral de 2015.

Dessa forma, importante perceber que esse formato de financiamento eleitoral vem se mostrando viável na França desde meados da década de 1990. Evidentemente, fraudes eventuais ocorrem em qualquer modelo de financiamento eleitoral - e, não diferentemente, ocorrem também no modelo adotado pela França mas o referido formato de financiamento eleitoral vem se mostrando funcional e adequado para manter a lisura do pleito eleitoral no país.

No entanto, em vez de levar a crer que o modelo francês poderia, ou deveria ser facilmente adotado no Brasil, importante frisar que o referido modelo opera bem na França porque o país regula de forma rígida os limites de gastos das campanhas eleitorais e de doações. Além disso, na França as campanhas têm

\footnotetext{
132 OSÓRIO, Aline. Direito Eleitoral e Liberdade de Expressão. Belo Horizonte: Fórum, 2017. p. 227

${ }^{133}$ BRASIL. Supremo Tribunal Federal. Acórdão na Ação Direta de Inconstitucionalidade. ADI n. 4.650. Tribunal Pleno. Requerente: Conselho Federal da Ordem dos Advogados do Brasil - CFOAB. Intimados: Presidente da República e Congresso Nacional. Relator: Luiz Fux. Voto do Ministro Luiz Fux. Brasília, 17 de setembro de 2015.
} 
duração curtíssima - 2 (duas) semanas para as campanhas presidenciais -, enquanto no Brasil as campanhas duravam cerca de 90 dias até a Minirreforma de 2015, e hoje duram aproximadamente 45 dias. Ou seja, é preciso atentar-se que a vedação de doações de pessoas jurídicas no modelo francês se mostra viável devido a esses três importantes fatores: limite de gastos, limite de doações e campanhas eleitorais de curta duração.

(v) Haveria ofensa ao princípio da igualdade se autorizada doação por parte de outras pessoas jurídicas, mas vedadas as doações por entidades sem fim lucrativos e sindicatos, como anteriormente posto pela lei. ${ }^{134}$

Muito embora o princípio da igualdade norteie o Direito Eleitoral no Brasil, ${ }^{135}$ antes da minirreforma eleitoral de 2015, a legislação vedava doações de determinadas pessoas jurídicas, como entidades sem fim lucrativos e sindicatos, enquanto autorizava doações de outras, como as empresas. Então, argumentava-se que esse tratamento diferenciado feriria o princípio da igualdade.

A França, como apresentado no capítulo anterior, veda doações de todas as pessoas jurídicas, exceto partidos ou grupos políticos. Essa distinção feita pela legislação eleitoral francesa não fere o princípio da igualdade, visto que, na França, partidos políticos são pessoas jurídicas de Direito Privado, que se submetem à legislação sobre o financiamento eleitoral, beneficiando-se de ajuda pública, mas devendo apresentar contas anuais à CNCCFP. ${ }^{136}$ Ou seja, partidos são pessoas jurídicas com primordial finalidade política, de forma que devem ser autorizadas, distintamente, a colaborar com financiamento estratégico para campanha de candidatos.

No Brasil, após o julgamento da ADI estudada e a minirreforma, todas as pessoas jurídicas passaram a ser proibidas de doar às campanhas eleitorais garantindo o direito de igualdade de tratamento entre as pessoas jurídicas, segundo

\footnotetext{
${ }^{134}$ BRASIL. Supremo Tribunal Federal. Acórdão na Ação Direta de Inconstitucionalidade. ADI n. 4.650. Tribunal Pleno. Requerente: Conselho Federal da Ordem dos Advogados do Brasil - CFOAB. Intimados: Presidente da República e Congresso Nacional. Relator: Luiz Fux. Voto do Ministro Luiz Fux. Brasília, 17 de setembro de 2015. 135 TAVARES, André Ramos; AGRA, Walber de Moura; PEREIRA, Luiz Fernando. O direito eleitoral e novo código de processo civil. Belo Horizonte: Fórum, 2016. p. 32

${ }^{136}$ FRANÇA. Vie publique au coeur du débat public. Les partis politiques. 2015. Disponível em: < http://www.vie-publique.fr/actualite/faq-citoyens/partis-politiques/>. Acesso em 27 jul. 2017
} 
o argumento defendido no julgamento do STF. No entanto, percebe-se que a minirreforma não se preocupou em assegurar a mesma igualdade de tratamento entre os eleitores - que são atualmente os únicos doadores. Isso porque, diferentemente da lei francesa, que estabelece um limite per capita único às doações de pessoas físicas, a lei brasileira insistiu em fixar o referido limite em percentual relativo aos rendimentos de cada pessoa física.

(iv) Não mereceria prosperar a alegação de que a vedação de doações não impediria as pessoas jurídicas de influenciar o processo político, pois estas se valeriam de formas ilícitas; ressaltando que se faz necessária, como sempre, a preocupação com 0 fortalecimento de mecanismos de fiscalização ${ }^{137}$

A França proibiu doações de pessoas jurídicas no financiamento de campanhas em meados da década de 1990, e tal proibição se mostra adequada e funcional no contexto francês de financiamento; pois a opinião pública entende que as regras eleitorais são cumpridas e não se observam fraudes sistemáticas à vedação. Ao contrário, no Brasil, mesmo antes de 2015, quando pessoas jurídicas podiam contribuir para campanhas eleitorais, dinheiro não contabilizado ("caixa dois") circulava sistematicamente no custeio das campanhas ${ }^{138}$ - fraudando as regras eleitorais.

Evidentemente, tem-se notícia de partidos e candidatos franceses que tentam burlar as regras eleitorais para maximizar seus recursos, ${ }^{139}$ mas, como já tratado anteriormente, o limite de gastos, bem definido e imposto por lei, acaba desestimulando campanhas caras, e, por consequência, os candidatos que por ventura se valham de recursos que ilicitamente ultrapassem o teto estipulado chamam atenção dos demais oponentes, da sociedade e da mídia. Assim, agentes políticos, a sociedade e a mídia são empoderadas na fiscalização das regras eleitorais de

\footnotetext{
${ }^{137}$ BRASIL. Supremo Tribunal Federal. Acórdão na Ação Direta de Inconstitucionalidade. ADI n. 4.650. Tribunal Pleno. Requerente: Conselho Federal da Ordem dos Advogados do Brasil - CFOAB. Intimados: Presidente da República e Congresso Nacional. Relator: Luiz Fux. Voto do Ministro Luiz Fux. Brasília, 17 de setembro de 2015. ${ }^{138}$ BRASIL. Supremo Tribunal Federal. Acórdão na Ação Direta de Inconstitucionalidade. ADI n. 4.650. Tribunal Pleno. Requerente: Conselho Federal da Ordem dos Advogados do Brasil - CFOAB. Intimados: Presidente da República e Congresso Nacional. Relator: Luiz Fux. Voto do Ministro Dias Toffoli. Brasília, 17 de setembro de 2015.

${ }^{139}$ BBC. Nicolas Sarkozy: A patchwork of ex-president's legal woes. 2017. Disponível em: <http://www.bbc.com/news/world-europe-28103690>. Acesso em: 27 jul. 2017
} 
financiamento, e eventuais fraudes são investigadas e penalizadas - por exemplo, como o que ocorreu com o ex-presidente francês, Nicolas Sarkozy, por ter ultrapassado o limite de gastos em sua campanha presidencial. ${ }^{140}$

\subsection{Possibilidades para o aprimoramento da Democracia Representativa no Brasil}

Do estudo da legislação eleitoral francesa, podem-se extrair algumas sugestões aplicáveis ao processo eleitoral brasileiro. A primeira sugestão, como tratada no bloco anterior, seria alterar o limite de doações de pessoas físicas, estipulando um valor per capita, como forma de conferir igualdade ao permitir que os eleitores se expressem.

Outra possibilidade, que precisaria ter sua viabilidade estudada mais a fundo, seria conceder abatimento parcial em tributo devido pelos eleitores que contribuíssem para o financiamento eleitoral - como acontece na França. Similarmente, os Estados Unidos adotam o sistema de "check off dolar", no qual os contribuintes podem optar por doar $\mathrm{U} \$ 3,00$ (três dólares) ao fundo de financiamento eleitoral ao preencherem suas declarações de imposto de renda, sem aumento na cobrança do imposto de renda. ${ }^{141}$ Medidas nesse sentido seriam positivas para a representatividade política, pois estimulariam a participação na política, reforçariam o vínculo do eleitor com os candidatos e a accountability por parte destes, caso o dinheiro doado fosse entregue diretamente à alguma campanha.

Sobre o modelo de financiamento eleitoral predominantemente público, alguns autores sugerem que este acarretaria em um certo "engessamento" dos partidos políticos que obteriam êxito nas eleições; uma vez que, como no caso da França, somente alguns partidos conseguiriam a ajuda financeira pública, pois precisam ter representação no Legislativo.

Todavia, Casas-Zamora e Zovatto defendem justamente o contrário ao explicitarem não haver evidências de tal efeito de engessamento dos partidos, visto

\footnotetext{
${ }^{140}$ LE FIGARO. Les finances des candidats á la présidentielle vont être davantage surveillées. Paris, 2016. Disponível em: <http://www.lefigaro.fr/politique/le-scan/2016/05/03/25001-20160503ARTFIG00324-lesfinances-des-candidats-a-la-presidentielle-vont-etre-davantage-surveillees.php>. Acesso em: 16 mar. 2017. ${ }^{141}$ GODOY, Arnaldo Sampaio de Moraes. O financiamento das eleições presidenciais nos Estados Unidos: da doutrina do one man, one vote ao dogma do one dollar, one vote. Universitas Jus, Brasília, v. 26, n. 2, 2015 , p. 11
} 
que em diversos países na América Latina o subsídio público é justamente o que permite partidos com menores relações com o setor privado consiguirem participar da corrida eleitoral. ${ }^{142}$ De fato, também na França, a eleição do presidente Emmanuel Macron é prova de que o financiamento predominantemente público não engessa por completo as chances de novos partidos. Macron foi vitorioso nas eleições de 2017 tendo montado seu partido no ano anterior; logo, sem nenhum representante no poder Legislativo. ${ }^{143}$ Portanto, a experiência francesa sugere que 0 financiamento predominantemente público, aliado a uma "cláusula de barreira", que restrinja o acesso dos partidos ao Fundo Partidário, não enrijeceria por completo, a ponto de determinar, necessariamente, os partidos que terão sucesso eleitoral.

Quanto aos partidos políticos, a proliferação destes é um problema no sistema eleitoral francês. Até 2013, havia 408 (quatrocentos e oito) partidos políticos oficialmente declarados na CNCCFP; um número quinze vezes maior do que na década de 1990. ${ }^{144}$ No entanto, desde 2011 a legislação eleitoral francesa se resguarda, como tratamos anteriormente, e só concede ajuda financeira a partidos com certa representação no poder Legislativo. ${ }^{145}$

Ora, quais seriam então as razões para a multiplicação de partidos políticos na França, se apenas cerca de 50 (cinquenta) partidos costumam estar aptos para receber financiamento público? O artigo do renomado jornal Le Monde explica o fenômeno: o objetivo dos micropartidos que vinham surgindo de forma crescente não seria eleger candidatos, mas sim receber doações de pessoas físicas para garantir financiamento complementar aos grandes partidos. Ocorre que a legislação francesa, atenta ao artifício criado, restringiu ainda mais as doações de pessoas físicas, em 2013. Antes, o indivíduo podia doar até $€ 7.500,00$ (sete mil e quinhentos euros), por ano, a cada partido. Depois da recente alteração legal, pessoas físicas podem doar o

\footnotetext{
${ }^{142}$ CASAS-ZAMORA, Kevin; ZOVATTO, Daniel. The Cost of Democracy: essays on Political Finance in Latin America. Costa Rica: IDEA, 2016, p.35

143 THE SPECTATOR. Who's behind the mysterious rise of Emmanuel Macron? 2017. Disponível em: < https://www.spectator.co.uk/2017/02/whos-behind-the-mysterious-rise-of-emmanuel-macron/>. Acesso em: 27 jul. 2017

${ }^{144}$ COMMISSION NATIONALE DES COMPTES DE CAMPAGNE ET DES FINANCEMENTS POLITIQUES. Publication générale des comptes des partis et groupements politiques au titre de l'exercice 2013. Disponível em: $<$ http://www.lemonde.fr/les-decodeurs/breve/2015/01/05/la-france-compte-15-fois-plus-de-partis-politiques-quil-y-a-25-ans_4549419_4355770.html>. Acesso em 16 mar. 2017.

145 BACKES, Ana Luiza. Financiamento partidário e eleitoral: Alemanha, França, Portugal e Espanha. Disponível:<http://www2.camara.leg.br/documentos-e-pesquisa/publicacoes/estnottec/areas-daconle/tema3/2012_22272.pdf >. Acesso em: 24 abr. 2016.
} 
mesmo valor por ano, no total. Dessa forma, muitos micropartidos perderam, em grande parte, sua razão de existir. ${ }^{146}$

Assim, a França foi capaz de identificar a causa da proliferação de micropartidos políticos e legislar no sentido de bloquear essa tendência. Entendeu-se que o número de partidos políticos não parece ter fundamento ideológico, mas, antes, motivações financeiras ${ }^{147}$. A experiência francesa pode ser de alguma utilidade para vislumbrar que a existência de muitos partidos no Brasil também pode ter forte motivação financeira. No entanto, soluções para a numerosidade de partidos no sistema eleitoral francês e brasileiro não poderiam ser discutidas no presente trabalho; restando apenas apontar a semelhança entre ambos os sistemas.

Por fim, na ADI n. 4.560, tratada anteriormente, o Ministro Gilmar Mendes pontuou importante aspecto dos gastos eleitorais, principalmente no que toca o Poder Executivo, ao afirmar que o candidato ou o partido do governo tem vantagem sobre os demais candidatos por poder se valer de propaganda institucional para se sobressair. ${ }^{148} \mathrm{Na}$ França, esse ponto parece estar mais em evidência. Isso porque a fiscalização feita pela CNCCPF já analisa todos os gastos do político que está no governo e concorre às eleições. Assim, mesmos os gastos com publicidade institucional, se considerados manifestamente eleitorais, são tidos como gastos de campanha. Por exemplo, em 2012, o ex-presidente francês Nicolas Sarkozy teve suas contas rejeitadas, entre outros problemas, porque despesas declaradas como institucionais foram consideradas despesas eleitorais. ${ }^{149}$ Portanto, se a intenção da vedação de contribuições de pessoas jurídicas no Brasil é equalizar a disputa eleitoral, então se faz necessário que o Brasil, como a França já fez, se atente aos gastos institucionais que tenham intenção eleitoral, e compute-os.

\footnotetext{
${ }^{146}$ LE MONDE. La France compte 15 fois plus de partis politiques qu'il y a 25 ans. Paris, 2015. Disponível em: $<\mathrm{http}: / /$ www.lemonde.fr/les-decodeurs/breve/2015/01/05/la-france-compte-15-fois-plus-de-partis-politiques-quil-y-a-25-ans_4549419_4355770.html>. Acesso em: 20 dez. 2016

147 BACKES, Ana Luiza. Financiamento partidário e eleitoral: Alemanha, França, Portugal e Espanha. Disponível: < http://www2.camara.leg.br/documentos-e-pesquisa/publicacoes/estnottec/areas-daconle/tema3/2012_22272.pdf >. Acesso em: 24 abr. 2016.

${ }^{148}$ BRASIL. Supremo Tribunal Federal. Acórdão na Ação Direta de Inconstitucionalidade. ADI n. 4.650. Tribunal Pleno. Requerente: Conselho Federal da Ordem dos Advogados do Brasil - CFOAB. Intimados: Presidente da República e Congresso Nacional. Relator: Luiz Fux. Voto do Ministro Gilmar Mendes. Brasília, 17 de setembro de 2015. Disponível em: <http://www.stf.jus.br/portal/processo/verProcessoAndamento.asp?incidente=4136819 >. Acesso em: 24 abr. 2016.

${ }^{149}$ LE FIGARO. Les finances des candidats á la présidentielle vont être davantage surveillées. Paris, 2016. Disponível em: <http://www.lefigaro.fr/politique/le-scan/2016/05/03/25001-20160503ARTFIG00324-lesfinances-des-candidats-a-la-presidentielle-vont-etre-davantage-surveillees.php>. Acesso em: 16 mar. 2017.
} 
Assim, resumidamente, as possibilidades vislumbradas neste trabalho para o aprimoramento da Democracia Representativa no Brasil são: garantir igualdade entre eleitores estabelecendo um valor específico como limite de doação de pessoas físicas; pensar em estratégias fiscais para promover maior participação de pessoas físicas no financiamento eleitoral; definir uma "cláusula de barreira" no financiamento predominantemente público; atentar-se à proliferação de partidos como estratégia para financiar grandes partidos - sendo que, no Brasil, isso poderia ser pensado no que tange às coligações, e aos gastos institucionais não computados como gastos eleitorais. 


\section{CONSIDERAÇÕES FINAIS}

O presente trabalho expõe que, com o julgamento da ADI n. 4.650 e a posterior entrada em vigor da Lei n. 13.165/15, vedando contribuições de pessoas jurídicas, o modelo de financiamento eleitoral brasileiro se aproximou do francês. Isso porque, na França, todas pessoas jurídicas, exceto partidos políticos, são proibidas de contribuir para campanhas eleitorais.

$\mathrm{Na}$ França, a participação de pessoas jurídicas no financiamento de campanhas e partidos já é vedada desde 1995. A legislação eleitoral francesa é rígida, se comparada com a regulação eleitoral brasileira antes da Minirreforma Eleitoral de 2015 (Lei n. 13.165/15), pois estabelece teto para os gastos eleitorais, tempo de campanha e regras para a propaganda eleitoral. Pela vedação de contribuições de pessoas jurídicas e também pelo estabelecimento de regras eleitorais detalhadas sobre o uso de dinheiro no pleito eleitoral, a legislação eleitoral brasileira atualmente em muito se assemelha à francesa. Em verdade, se os pedidos da ADI estudada tivessem sido deferidos pelo Supremo Tribunal Federal, o financiamento eleitoral no Brasil teria se tornado ainda mais semelhante ao modelo francês; pois teria sido estipulado limite uniforme para doações de pessoas físicas.

A legislação francesa optou por reforçar o financiamento público como forma de suprir os recursos necessários às campanhas e aos partidos, e garantir maior equidades entre estes. No entanto, o estudo permitiu a compreensão de que um generoso financiamento público não resolve a relação entre pessoas jurídicas e o financiamento eleitoral, mas apenas quando combinado com toda uma estrutura institucional. ${ }^{150}$ Assim, uma vez optado por seguir modelo semelhante ao francês, o financiamento eleitoral no Brasil deveria também se preocupar com outras regras importantes para a eficácia do financiamento predominantemente público, como limite de gastos eleitorais, tempo de campanha - que já foram cuidados pela Minirreforma Eleitoral de 2015 - bem como com a proliferação de partidos políticos como estratégia de financiamento, gastos institucionais com clara intenção eleitoral, cláusula de

\footnotetext{
${ }^{150}$ CASAS-ZAMORA, Kevin; ZOVATTO, Daniel. The Cost of Democracy: essays on Political Finance in Latin America. Costa Rica: IDEA, 2016, p. 35
} 
barreira para o acesso ao Fundo Partidário, e o incentivo da participação de pessoas físicas no financiamento eleitoral.

A partir das legislações brasileira e francesa, o presente trabalho relaciona como o financiamento de eleições pode refletir na consolidação de uma Democracia Representativa; uma vez que, em Democracias Representativas, eleições são a forma como o povo participa da vontade do governo e no processo político. ${ }^{151}$ Nas palavras de José Afonso da Silva:

\begin{abstract}
Realmente, nas democracias de partido e sufrágio universal, as eleições tendem a ultrapassar a pura função designatória para se transformarem num instrumento, pelo qual o povo adere a uma política governamental e confere seu consentimento, e por consequência, legitimidade, às autoridades governamentais. ${ }^{152}$
\end{abstract}

Atualmente, cidadãos declaram-se, frequentemente, descrentes na classe política, nos partidos, e não consideram seus governantes como bons representantes - o que, na França, se verifica, por exemplo, pelo alto número de abstenções nas eleições. ${ }^{153}$ Esse fenômeno foi intitulado "crise de representatividade" e acomete tanto a política francesa quanto a brasileira.

Nessa lógica, a França parece se preocupar com a igualdade de condições de candidatos e partidos como forma de assegurar a representatividade política. $O$ estudo apresentou que, mesmo com suas marcantes especificidades, a lei francesa há muito proíbe doações diretas de empresas a campanhas.

Fica evidenciado que, como a França, o Brasil hoje entende haver uma incompatibilidade entre pessoas jurídicas, especialmente empresas, e o pleito eleitoral; e que o direito de expressão das pessoas jurídicas não deve prevalecer frente ao interesse público. Ademais, a experiência francesa demonstra que a ajuda de pessoas jurídicas não é essencial para a viabilização de campanhas eleitorais.

Nesse sentido, e como exposto no trabalho, a forma como os candidatos custeiam suas campanhas tem impacto no resultado eleitoral, de forma que o financiamento eleitoral se relaciona à representatividade. Importante, então, notar

\footnotetext{
${ }^{151}$ SILVA, José Afonso da. Curso de Direito Constitucional Positivo. 25. ed. São Paulo: Malheiros Editores, 2005. p. 137

152 Ibidem, p. 137, grifo nosso.

${ }^{153}$ FRANÇA. Vie publique au coeur du débat public. Quel est le rôle des partis politiques? 2013. Disponível em: <http://www.vie-publique.fr/decouverte-institutions/citoyen/participation/parti-politique/quel-est-role-partispolitiques.html>. Acesso em 27 jul. 2017
} 
que, no que tange à participação de pessoas jurídicas no financiamento eleitoral, desde o começo da década de 1990, o Brasil vedava doações de pessoas jurídicas, em seguida passou a autorizar, e, recentemente, voltou a vedar tais doações. A França, por outro lado, no mesmo intervalo de tempo, optou por vedar a participação destas no financiamento e assim vem sendo regulado o financiamento eleitoral; e, apesar de eventuais irregularidades, o modelo francês vem se mostrando funcional.

Assim, nota-se que as experiências durante os trinta primeiros anos de amadurecimento da democracia brasileira fizeram-na proibir a participação de pessoas jurídicas no financiamento eleitoral, adotando inclinação semelhante à França, em um esforço de proporcionar igualdade de oportunidades e paridade de armas entre os candidatos no pleito eleitoral. 


\section{REFERÊNCIAS}

ABRAMO, Claudio Weber. Corrupção no Brasil: A perspectiva do setor privado. 2004. Disponível em: <http://www.transparencia.org.br/docs/perspec-privado2003.pdf>. Acesso em: 10 abr. 2016.

ANKERSMIT, Frank. Democracia Representativa. Revista Antíteses, Londrina, v. 6, n.12, jul./dez. 2013.

ARAÚJO, Victor; SILOTTO, Graziele; CUNHA, Lucas Rodrigues. Capital político e financiamento eleitoral no Brasil: uma análise empírica das estratégias das empresas na alocação de recursos de campanha. Teoria e Sociedade, n. 23, v.2, p.126-158, jul./dez. 2015.

ASSEMBLÉE NATIONALE. Fiche de synthèse $n$. 15: Le financement de la vie politique, partis et campagnes électorales. Disponível em: < http://www2.assembleenationale.fr/decouvrir-l-assemblee/role-et-pouvoirs-de-l-assemblee-nationale/ledepute/le-financement-de-la-vie-politique-partis-et-campagnes-electorales>. Acesso em: 20 dez. 2016.

BACKES, Ana Luiza. Financiamento partidário e eleitoral: Alemanha, França, Portugal e Espanha. Disponível: < http://www2.camara.leg.br/documentos-epesquisa/publicacoes/estnottec/areas-da-conle/tema3/2012_22272.pdf >. Acesso em: 24 abr. 2016.

BACKES, Ana Luiza; SANTOS, Luiz Cláudio Pires dos. Gastos em campanhas eleitorais no Brasil. Cadernos ASLEGIS, Brasília, n. 46, p. 47-59, maio/ago. 2012

BANDEIRA, Regina Maria Groba. Sistemas de governo no Brasil, na França e nos Estados Unidos da América. Câmara dos Deputados, Brasília, fev. 2015.

BBC. Nicolas Sarkozy: A patchwork of ex-president's legal woes. 2017. Disponível em: <http://www.bbc.com/news/world-europe-28103690>. Acesso em: 27 jul. 2017

BRASIL. Câmara dos Deputados. Câmara conclui votação da minirreforma eleitoral e mantém doação de empresas a partidos. Disponível em:

$<$ http://www2.camara.leg.br/camaranoticias/noticias/politica/495798-camara-concluivotacao-da-minirreforma-eleitoral-e-mantem-doacao-de-empresas-a-partidos.html>. Acesso em: 3 out. 2016.

BRASIL. Câmara dos Deputados. Proposta estabelece limites para gastos eleitorais. Disponível em:

<http://www2.camara.leg.br/camaranoticias/noticias/POLITICA/475470-PROPOSTAESTABELECE-LIMITES-PARA-GASTOS-ELEITORAIS.html>. Acesso em: 18 mar. 2017. 
BRASIL. Constituição (1988). Constituição da República Federativa do Brasil. Brasília: Senado Federal, 2010.

BRASIL. Lei n. 13.165, de 29 de setembro de 2015. Disponível em: <http://www.planalto.gov.br/ccivil_03/_ato2015-2018/2015/lei//13165.htm >. Acesso em: 24 abr. 2016.

BRASIL. Lei n. 5.682, de 21 de julho de 1971. Lei orgânica dos partidos. Disponível em: <http://www.planalto.gov.br/ccivil_03/leis/1970-1979/L5682.htm>. Acesso em: 20 mar. 2017.

BRASIL. Lei n. 9.096, de 19 de setembro de 1995. Dispõe sobre partidos políticos, regulamenta os arts. 17 e 14, § 3ำ, inciso V, da Constituição Federal. Disponível em: <http://www.planalto.gov.br/ccivil_03/leis/L9096.htm >. Acesso em: 24 abr. 2016.

BRASIL. Lei n. 9.504, de 30 de setembro de 1997. Estabelece normas para as eleições. Disponível em: < http://www.planalto.gov.br/ccivil_03/LEIS/L9504.htm >. Acesso em: 24 abr. 2016.

BRASIL. Lei n. 10.406, de 10 de janeiro de 2002. Institui o Código Civil. Disponível em: <http://www.planalto.gov.br/ccivil_03/leis/2002/L10406.htm>. Acesso em: 16 mar. 2017.

BRASIL. Proposta de Emenda à Constituição no 113A, de 2015. Disponível em: $<$ http://www.senado.gov.br/atividade/materia/getPDF.asp?t=184928\&tp=1>. Acesso em: 10 de nov. 2016.

BRASIL. Supremo Tribunal Federal. Acórdão na Ação Direta de Inconstitucionalidade. $A D I$ n. 4.650. Tribunal Pleno. Requerente: Conselho Federal da Ordem dos Advogados do Brasil - CFOAB. Intimados: Presidente da República e Congresso Nacional. Relator: Luiz Fux. Voto do Ministro Gilmar Mendes. Brasília, 17 de setembro de 2015. Disponível em:

$<$ http://www.stf.jus.br/portal/processo/verProcessoAndamento.asp?incidente $=413681$ 9 >. Acesso em: 24 abr. 2016.

BRASIL. Supremo Tribunal Federal. Acórdão na Ação Direta de Inconstitucionalidade. ADI n. 5.105. Tribunal Pleno. Requerente: Solidariedade. Intimados: Presidente da República, Advogado-Geral da República e Congresso Nacional. Relator: Luiz Fux. Brasília, 1 de outubro de 2015. Disponível em: $<$ http://www.stf.jus.br/portal/processo/verProcessoAndamento.asp?numero=5105\&cl asse $=$ ADI\&codigoClasse $=0$ \&origem $=J U R \&$ recurso $=0$ \&tipoJulgamento $=M>$. Acesso em: 17 mar. 2017.

BRASIL. Supremo Tribunal Federal. Andamento Processual da ADI n. 4.650. Disponível em:

$<$ http://www.stf.jus.br/portal/processo/verProcessoAndamento.asp?incidente=413681 9>. Acesso em: 3 out. 2016. 
BRASIL. Supremo Tribunal Federal. Glossário Jurídico. Disponível em: $<$ http://www.stf.jus.br/portal/glossario/verVerbete.asp?letra=A\&id=124>. Acesso em: 3 out. 2016.

CANOTILHO, José Joaquim Gomes. Direito constitucional e teoria da constituição. 3.ed. Coimbra: Almedina, 1998.

CASAS-ZAMORA, Kevin; ZOVATTO, Daniel. The Cost of Democracy: essays on Political Finance in Latin America. Costa Rica: IDEA, 2016.

CHRIMES, Stanley Bertram. English Constitutional History. London, Oxford University Press, 1947.

COMA, Ferran Martínez et al. The Year in Elections, 2015: The expert survey on perceptions of electoral integrity. Sydney: Electoral Integrity Project, 2016.

COMMISSION NATIONALE DES COMPTES DE CAMPAGNE ET DES FINANCEMENTS POLITIQUES. Publication générale des comptes des partis et groupements politiques au titre de l'exercice 2013. Disponível em: <http://www.lemonde.fr/les-decodeurs/breve/2015/01/05/la-france-compte-15-foisplus-de-partis-politiques-qu-il-y-a-25-ans_4549419_4355770.html>. Acesso em 16 mar. 2017.

CUNHA, André Luiz Nogueira da. Direitos políticos: representatividade, capacidade eleitoral e inelegibilidades. São Paulo: Juarez de Oliveira, 2004.

DALLARI, Dalmo de Abreu. Elementos de teoria geral do estado. 22. ed. São Paulo: Saraiva, 2001.

FILHO, Dalson Britto Figueiredo. Gastos Eleitorais: os determinantes das eleições? Estimando a influência dos gastos de campanha nas eleições de 2002. Revista Urutágua, v. 8, p. 1-10, 2005.

FRANÇA. Article L52-11 modifié par LOI n²015-1268 du 14 octobre 2015 - art. 38. Disponível em:

<https://www.legifrance.gouv.fr/affichCodeArticle.do?cidTexte=LEGITEXT000006070 239\&idArticle=LEGIARTI000031325083\&dateTexte=20170319>. Acesso em: 18 mar. 2017.

FRANÇA. Cour de Cassation. Disponível em: <https://www.courdecassation.fr/>. Acesso em: 20 dez. 2016.

FRANÇA. Décret $n^{\circ}$ 2009-1730 du 30 décembre 2009 portant majoration du plafond des dépenses électorales. Disponível em:

<https://www.legifrance.gouv.fr/affichTexte.do?cidTexte=JORFTEXT000021571255\& categorieLien=cid>. Acesso em: 17 mar. 2017 
FRANÇA. Le conséil d'Etat et la jurisdition administrative. Disponível em: <http://www.conseil-etat.fr/Conseil-d-Etat/Missions>. Acesso em: 20 dez. 2016.

FRANÇA. Le conséil d'Etat et la jurisdition administrative. Disponível em: <http://www.conseil-etat.fr/Conseil-d-Etat/Missions>. Acesso em: 20 dez. 2016.

FRANÇA. Lei n. 2013-907, de 11 de outubro de 2013. Dispões sobre a transparência na vida pública. Paris,2013. Disponível em:

<https://www.legifrance.gouv.fr/affichTexte.do?cidTexte=JORFTEXT000028056315> . Acesso em: 20 dez. 2016.

FRANÇA. Vie publique au coeur du débat public. Comment devient-on président de la République? Paris, 2017. Disponível em: < http://www.vie-publique.fr/decouverteinstitutions/institutions/fonctionnement/president-republique/comment/comment-estfinancee-campagne-electorale.html>. Acesso em: 18 mar. 2017.

FRANÇA. Vie publique au coeur du débat public. Les partis politiques. 2015. Disponível em: < http://www.vie-publique.fr/actualite/faq-citoyens/partis-politiques/>. Acesso em 27 jul. 2017

FRANÇA. Vie publique au coeur du débat public. Quel est le rôle des partis politiques? 2013. Disponível em: <http://www.vie-publique.fr/decouverteinstitutions/citoyen/participation/parti-politique/quel-est-role-partis-politiques.html>. Acesso em 27 jul. 2017

FRANÇA. Vie publique au coeur du débat public. Quel est le statut juridique d'um citoyen? 2013. Disponível em: < http://www.vie-publique.fr/decouverteinstitutions/citoyen/citoyennete/definition/definir/quel-est-statut-juridique-citoyen.html >. Acesso em 27 jul. 2017

FRANCK, Louis R. The future of representative democracy. Foreign Affairs, Tampa, v. 24, n. 2, jan. 1946.

KANG, Michael S. The end of Campaign Finance Law. Virginia Law Review, Charlottesville, v. 98, n. 1, mar. 2012.

KEANE, John. A vida e a morte da democracia. São Paulo: Edições 70, 2010.

KUHNER, Timothy K. Plutocracy and partyocracy. Rev. Const. Stud. n.1, v.21, 2016, p. $115-142$.

LE FIGARO. Il faut diversifier les sources de financement de la politique et améliorer le contrôle. Paris, 2016. Disponível em: <http://www.lefigaro.fr/politique/2016/09/06/01002-20160906ARTFIG00227-il-fautdiversifier-les-sources-de-financement-de-la-politique-et-ameliorer-le-controle.php>. Acesso em: 20 dez. 2016. 
LE FIGARO. Les finances des candidats á la présidentielle vont être davantage surveillées. Paris, 2016. Disponível em: <http://www.lefigaro.fr/politique/lescan/2016/05/03/25001-20160503ARTFIG00324-les-finances-des-candidats-a-lapresidentielle-vont-etre-davantage-surveillees.php>. Acesso em: 16 mar. 2017.

LE MONDE. D'où vient le financement des partis politiques? Paris, 2017. Disponível em: <http://www.lemonde.fr/les-decodeurs/article/2017/02/10/d-ou-vient-lefinancement-des-partis-

politiques_5077918_4355770.html?xtmc=financement_des_partis_politiques\&xtcr=2 >. Acesso em: 16 mar 2017.

LE MONDE. La France compte 15 fois plus de partis politiques qu'il y a 25 ans.

Paris, 2015. Disponível em: <http://www.lemonde.fr/les-

decodeurs/breve/2015/01/05/la-france-compte-15-fois-plus-de-partis-politiques-qu-ily-a-25-ans_4549419_4355770.html>. Acesso em: 20 dez. 2016.

LIBRARY OF CONGRESS. Campaign finance: France. Disponível em: $<$ https://www.loc.gov/law/help/campaign-finance/france.php>. Acesso em: $20 \mathrm{dez}$. 2016.

MARCONI, Marina de Andrade; LAKATOS, Eva Maria. Fundamentos de Metodologia Científica. 7. ed. São Paulo: Atlas, 2010.

MARQUES, Meire Aparecida; RIBEIRO, Thiago Bao. Para além da democracia representativa: uma crítica ao modelo tradicional de representatividade política nas democracias modernas. Revista Jurídica UniCuritiba, Curitiba, v. 2, n. 39, p. 325-349, 2015.

MEUNIER, Sophie. The French presidency is a bargain. Disponível em: $<$ http://www.huffingtonpost.com/sophie-meunier/france-electionlaws_b_1438456.html>. Acesso em 20 mar. 2017.

MILL, John Stuart. Representative government. Kitchener: Batoche Books, 2001.

OSÓRIO, Aline. Direito Eleitoral e Liberdade de Expressão. Belo Horizonte: Fórum, 2017. p. $17-445$

PAIVA, Denise; BRAGA, Maria do Socorro S.; PIMENTEL JR., Jairo Tadeu Pires. Eleitorado e partidos políticos no Brasil. Opinião Pública, Campinas, v. 13, n. 2, p. 388408, nov. 2007. Disponível em: $<$ http://www.scielo.br/scielo.php?script=sci_arttext\&pid=S010462762007000200007\&lng=en\&nrm=iso>. Acesso em: 30 mar. 2017.

PITKIN, Hanna Fenichel. Representation and Democracy: Uneasy Alliance. Scandinavian Political Studies. Denmark; Finland; Iceland; Norway; Sweden: v. 27, n. 3, p.335, set/2004. 
REINER, Lúcio. França: Ética e transparência na política. Brasília: Câmara dos Deputados, Brasília, set. 2001.

SACCHET, Teresa; SPECK, Bruno Wilhelm. Financiamento Eleitoral e Representação Política: O peso do dinheiro e o desequilíbrio de gênero nas esferas legislativas. 34ํㅜㄴ encontro anual da ANPOCS, Caxambu-MG, out. 2010.

SALGADO, Eneida Desireé. Abuso do poder econômico e financiamento das campanhas eleitorais. Curitiba. Disponível em:< http://www.paranaeleitoral.gov.br/artigo_impresso.php?cod_texto $=10>$. Acesso em.: 27 out 2007.

SALLUM JR., Brasílio.; CASARÕES, Guilherme Stolle Paixão e. O impeachment do presidente Collor: a literatura e o processo. Lua Nova, n. 82, p. 163-200, 2011. Disponível em: <http://www.scielo.br/scielo.php?script=sci_arttext\&pid=S0102$64452011000100008 \& \operatorname{lng}=e n \& n r m=i s o>$. Acesso em: 03 out. 2016.

SAMUELS, David. Financiamento de Campanhas no Brasil e Propostas de Reforma. Suffragium, v. 3, n. 4, p. 11-28, jan./jun. 2007.

SARMENTO, Daniel; OSÓRIO, Aline. Eleições, dinheiro e democracia: a ADI 4650 e o modelo de financiamento de campanhas eleitorais. Direitos Fundamentais e Justiça, ano 8, n. 26, jan./mar. 2014

SILVA, José Afonso da. Curso de Direito Constitucional Positivo. 25. ed. São Paulo: Malheiros Editores, 2005. p. 9-921

SILVEIRA, José Neri da. Aspectos do processo eleitoral. Porto Alegre: Livraria do advogado, 1998.

SPECK, Bruno; WAGNER, Mancuso. O que faz a diferença? Gastos de campanha, capital, política, sexo e contexto municipal nas eleições para prefeito em 2012 . Cadernos Adenauer XIV, n. 2, 2013.

STEPHENSON, Carl. Medieval Institutions. Ithaca, Nova York: Cornell University Press, 1954.

TAVARES, André Ramos; AGRA, Walber de Moura; PEREIRA, Luiz Fernando. O direito eleitoral e novo código de processo civil. Belo Horizonte: Fórum, 2016. p. 1-485

THE SPECTATOR. Who's behind the mysterious rise of Emmanuel Macron? 2017. Disponível em: < https://www.spectator.co.uk/2017/02/whos-behind-the-mysteriousrise-of-emmanuel-macron/>. Acesso em: 27 jul. 2017

XAVIER, Allan Ferreira. O financimento de campanha e sua influencia na representação. Brasília: Vestnik, 2014. p. 1-97. 